\title{
Ceramic Cutting Materials and Tools Suitable for Machining High-Temperature Nickel-Based Alloys: A Review
}

\author{
Anton Seleznev $^{1, *(\mathbb{D})}$, Nestor Washington Solis Pinargote ${ }^{2}$ and Anton Smirnov and $^{2, *(D)}$ \\ 1 Spark Plasma Sintering Research Laboratory, Moscow State University of Technology "STANKIN", \\ Vadkovsky per. 1, Moscow 127055, Russia \\ 2 Laboratory of 3D Structural and Functional Engineering, Moscow State University of Technology \\ “STANKIN", Vadkovsky per. 1, Moscow 127055, Russia; nw.solis@stankin.ru \\ * Correspondence: a.seleznev@stankin.ru (A.S.); a.smirnov@stankin.ru (A.S.); \\ Tel.: +7-4999-7323-70 (A.S. \& A.S.)
}

check for

updates

Citation: Seleznev, A.; Pinargote, N.W.S.; Smirnov, A. Ceramic Cutting Materials and Tools Suitable for Machining High-Temperature NickelBased Alloys: A Review. Metals 2021, 11, 1385. https://doi.org/10.3390/ met11091385

Academic Editors: Soran Birosca and Lijun Zhang

Received: 19 May 2021

Accepted: 25 August 2021

Published: 31 August 2021

Corrected: 25 April 2022

Publisher's Note: MDPI stays neutral with regard to jurisdictional claims in published maps and institutional affiliations.

Copyright: (C) 2021 by the authors. Licensee MDPI, Basel, Switzerland. This article is an open access article distributed under the terms and conditions of the Creative Commons Attribution (CC BY) license (https:/ / creativecommons.org/licenses/by/ $4.0 /)$.

\begin{abstract}
Nickel-based superalloys are attractive to many industrial sectors (automotive, military, energy, aerospace, etc.). However, their physical properties make them difficult to machining using traditional tools. Therefore, new materials for the machining of Ni-based alloys are required. Ceramicbased composites could act as a tool to replace the current materials. The incentives for this paper are to provide an overview of existing ceramic composites and draw some conclusions that will help in solving the problem of choosing materials for the processing of Ni-based superalloys. Despite the diversity of ceramic composites in this work, the possibility of using the SiAlON ceramic for Ni-based alloy machining is highlighted.
\end{abstract}

Keywords: nickel-based superalloys; ceramic instruments; carbides; cubic boron nitride; cermet; SiAlON

\section{Introduction}

Superalloys show high strength, corrosion or oxidation resistance at elevated temperatures, and creep resistance [1-4]. The most classic type of superalloy is nickel-based superalloys. They are mainly used for aerospace, oil and gas mining, petrochemical, and other industrial sectors [5-7].

Nickel-based superalloys are often categorised in terms of chemical composition. Inconel 718 remains one of the most researched grades of nickel-based superalloys in terms of surface integrity aspects [8-22]. Other grades of nickel-based superalloys that have received attention among researchers include ME-16 [23-27], RR1000 [28-33], IN100 [34-37], and FGH95 [36-39], produced through powder metallurgy (PM) techniques and Udimet 720LI $[38,39]$ which also find applications in aerospace and automobile industries [40-48]. Nimonic 80 A (according to DIN 17,742 its alloy mark is NiCr20TiAl, W.Nr. $2.4952,2.4631$ [49]), due to its high resistance to pressure, temperature, and water vapour, is extensively used after solution and precipitation treatment in key parts of large-scale power steam turbines [49,50]. Inconel 825 offers considerable resistance to corrosive environments and hence is suitable for application in acid production, chemical processing, oil and gas recovery, acid production, handling of radioactive wastes, pollution control, nuclear fuel reprocessing, and pickling operations [51-54]. Other grades of nickel-based superalloys, including Nimonic C-263 [55-64], Nimonic-75, and Nimonic-105 [65], are mainly used in the hot combustion chamber of gas turbines. Integrally cast IN-713LC cast superalloys are used in rotor blades for gas turbines, aircraft turbines, and rotor wheels [66-69]. The chemical composition and properties of these superalloys are provided in Table 1.

Different alloying elements have their own contributions in affecting the properties of various grades of the superalloys. $\mathrm{Al}$ and $\mathrm{Cr}$ primarily impart resistance to oxidation, whereas elements such as $\mathrm{Cr}, \mathrm{Mo}, \mathrm{W}, \mathrm{Nb}, \mathrm{Ta}, \mathrm{Ti}$, and $\mathrm{Hf}$ are used to reinforce grain boundaries by forming carbides and precipitating along grain boundaries. 
Table 1. Various categories, compositions, and characteristics of nickel-based alloys.

\begin{tabular}{|c|c|}
\hline $\begin{array}{c}\text { Various Categories of } \\
\text { Nickel-Based Superalloys }\end{array}$ & Composition \\
\hline Inconel 718 & $\begin{array}{c}\text { Ni 54.48, Cr 17.50, Fe 22.3, } \\
\text { Nb 4.90, Al 0.66, Ti } 0.96\end{array}$ \\
\hline Inconel 100 & $\begin{array}{c}\mathrm{Ni} 60, \mathrm{Cr} 10, \mathrm{Co} 15, \mathrm{Mo} 3, \\
\mathrm{Al} 5.5, \mathrm{Ti} 4.7, \mathrm{C} 0.18, \mathrm{~B} 0.014, \\
\text { Zr } 0.06\end{array}$ \\
\hline Inconel 825 & $\begin{array}{c}\text { Ni 37.1, Fe 32.2, Cr 22.8, } \\
\text { Mo 3.24, Cu 2.07, Ti 0.859, } \\
\text { C } 0.0155\end{array}$ \\
\hline IN-713LC & $\begin{array}{l}\text { Ni 74.2, Cr 12.6, Mo 4.9, } \\
\text { Nb 1.96, Al 5.7, Zr 0.1, Ti 0.63, } \\
\text { C } 0.047 \text {, B } 0.007\end{array}$ \\
\hline
\end{tabular}

Precipitation hardenable, high creep-rupture strength at high temperatures to about $700{ }^{\circ} \mathrm{C}$, and excellent strength.

Precipitates of primary niobium carbide $(\mathrm{NbC})$, titanium carbide (TiC) disk-shaped gamma double prime $\left(\gamma^{\prime \prime}\right)$ precipitates $\left(\mathrm{Ni}_{3} \mathrm{Nb}\right)$, and needle-like precipitates of $\delta\left(\mathrm{Ni}_{3} \mathrm{Nb}\right)$ present.

Precipitation hardenable, high rupture strength through $870{ }^{\circ} \mathrm{C}$.

The high percentages of titanium, aluminium, and low refractory metal increase strength-to-density ratio.

Good resistance to pitting, intergranular corrosion, chloride-ion stress-corrosion cracking, and general corrosion in a wide range of oxidising and reducing environments.

Good combination of tensile and creep-rupture properties as a result of gamma-prime strengthening enhanced by solid solution and grain-boundary strengthening, and good castability.

Solid solution strengthened with tungsten and molybdenum and precipitation-hardened with titanium and aluminium.

Udimet 720LI Ni 57.4, Cr 16, Co 15, Mo 3, Ti 5, Al 2.5, W1, C 0.1

High strength, excellent impact strength retention at elevated temperatures, good oxidation and corrosion resistance, and high degree of work hardening.

\begin{tabular}{|c|c|c|}
\hline & & \\
\hline FGH95 & $\begin{array}{l}\mathrm{Ni} 62.5, \mathrm{Cr} 12.98, \mathrm{Co} 8.00, \mathrm{Nb} \\
\text { 3.50, Al 3.48, Ti 2.55, W 3.40, } \\
\text { Mo 3.40, C 0.060, B } 0.012\end{array}$ & $\begin{array}{c}\text { Precipitation hardened having higher tensile and yield strength } \\
\text { at } 650^{\circ} \mathrm{C} \text {. A compact structure after hot isostatic pressing (HIP) } \\
\text { consisting of coarse gamma prime phase }\left(\gamma^{\prime}\right) \text { precipitated along } \\
\text { previous particle boundaries (PPB) appear in the grain. }\end{array}$ \\
\hline ME-16 & $\begin{array}{l}\text { Ni 56.3, Cr 10.4, Co } 20.5 \\
\text { Al 3.1, Ti 2.6, W 3, Ta } 1.4 \\
\text { Mo } 1.3, \mathrm{Nb} 1.4\end{array}$ & $\begin{array}{c}\text { Good strength and creep resistance at high temperatures } \\
\left(600-800^{\circ} \mathrm{C}\right) \text {. Good resistance to fatigue crack initiation at the } \\
\text { lower temperatures }\left(300-600^{\circ} \mathrm{C}\right) \text {. Can maintain strength and } \\
\text { lower density at elevated temperature. }\end{array}$ \\
\hline RR1000 & $\begin{array}{l}\text { Ni 52.4, Cr 15, Co 18.5, Mo 5, } \\
\text { Ti 3.6, Al 3, Ta 2, Hf 0.5, C } 0.03\end{array}$ & $\begin{array}{l}\text { Solid solution strengthened with chromium, molybdenum, and } \\
\text { cobalt. Good strength, good toughness, creep resistance, good } \\
\text { oxidation, and corrosion resistance at high temperatures. }\end{array}$ \\
\hline Nimonic C-263 & $\begin{array}{l}\text { Ni 51.0, Cr 20.0, Co 20.0, } \\
\quad \text { Mo 5.8, Ti 2.2, } \mathrm{Al} 0.5\end{array}$ & $\begin{array}{l}\text { A readily weldable, age-hardenable superalloy with excellent } \\
\text { strength, ductility, and corrosion resistance up to around } 850^{\circ} \mathrm{C} \text {. } \\
\text { Molybdenum for solid-solution strengthening. }\end{array}$ \\
\hline Nimonic 105 & $\begin{array}{l}\text { Ni 54.0, Co 20.0, Cr 15.0, } \\
\quad \text { Mo 5.0, Al 4.7, Ti } 1.3\end{array}$ & $\begin{array}{l}\text { An age-hardenable superalloy within creased aluminium for } \\
\text { improved oxidation-resistance and strength, and high } \\
\text { creep-rupture properties up to around } 950^{\circ} \mathrm{C} \text {. Strengthened by } \\
\text { additions of molybdenum, aluminium, and titanium. }\end{array}$ \\
\hline Nimonic 75 & Ni 80.5, Cr 19.5 & $\begin{array}{l}\text { Good corrosion and heat resistance, high-temperature strength, } \\
\text { and outstanding oxidation resistance. }\end{array}$ \\
\hline Nimonic $80 \mathrm{~A}$ & Ni 76.0, Cr 19.5, Ti 2.4, Al 1.4 & $\begin{array}{l}\text { An age-hardenable creep-resistant alloy for service at } \\
\text { temperatures up to around } 815^{\circ} \mathrm{C} \text {. }\end{array}$ \\
\hline Hastelloy alloy C-2000 & $\begin{array}{l}\text { Ni } 47, \operatorname{Cr} 22, \text { Fe } 18, \text { Mo } 9 \\
\text { Co } 1.5, \text { W } 0.6\end{array}$ & $\begin{array}{l}\text { Localised corrosion resistance, good resistance to hot acids, and } \\
\text { excellent resistance to stress-corrosion cracking. }\end{array}$ \\
\hline Haynes 282 & $\begin{array}{l}\text { Ni 57, Cr 20, Co 10, Mo 8.5, } \\
\text { Ti 2.1, Al 1.5, Fe 1.5, Mn 0.3, } \\
\text { Si 0.15, C 0.06, B } 0.005\end{array}$ & $\begin{array}{l}\gamma^{\prime} \text { precipitation strengthened nickel-based superalloy along } \\
\text { with excellent creep properties, fabricability, and } \\
\text { thermal stability. }\end{array}$ \\
\hline
\end{tabular}

However, despite the exceptional properties of Ni-based superalloys, the problem of machining continues to exist due to their high strength and plastic viscosity [70-74]. There 
is a series of problems in the usual processing of nickel-based superalloys including the following:

- Due to the low ability to conduct heat, the thermal generated while processing of workpieces is not passed to the chips or the rough part but is concentrated on the cutting edges, which leads to crater wear and extensive plastic deformation of the cutting tool edge;

- Increased crater wear results in severe damage of cutting instrument and plastic strain causes high resistance of the material against during the intrusion of the cutting tool;

- Metal pickup and coating delamination due to the chemical reaction of Ni-based superalloys during machining reduces tool life;

- High wear on the cutting edge of the tool generated by friction because of the occurrence of solid and abrasive intermetallic compounds in the microstructure of these alloys;

- Changes in the microstructure of the alloys due to high heat generation during machining and generated residual stresses cause a further reduction in the cyclic life of the component;

- In addition, the machining of these alloys also leads to high cutting emulsion consumption, the cost of which corresponds to the cost of cutting instruments [75].

Based on the above-listed drawbacks, the manufacturers are interested in minimising the losses at all stages in the processing chain. Therefore, new tool materials or other technical solutions for Ni-based superalloys machining are needed. The use of ceramics as a cutting tool could be proposed as a possible solution to these challenges. Ceramic tool materials exhibit very high hardness and wear resistance, high resistance to plastic deformation, and chemical stability. The diversity of ceramic tool grades appearing each year on the market indicates that these materials are promising. Ceramic tools are used for a broad range of materials and processing operations, including also high-speed finishing machining of superalloys. The most promising group of ceramic materials for machining of Ni-based superalloys is mixed nitride and oxide ceramic - namely, SiAlON [76-86]. SiAlON provides excellent resistance to high temperatures, mechanical strength even when subjected to high temperatures, good thermal shock resistance and good wear resistance, high toughness, and outstanding thermal shock resistance. In addition, this class of ceramic possesses improved sinterability, compared to silicon nitride. In our previous article, we provided basic information about this type of material [87]. Briefly, SiAlONs are formed when silicon nitride $\left(\mathrm{Si}_{3} \mathrm{~N}_{4}\right)$, aluminium oxide $\left(\mathrm{Al}_{2} \mathrm{O}_{3}\right)$, and aluminium nitride (AlN) react together. $\alpha$-SiAlON and $\beta$-SiAlON represent the two main phases of this type of ceramic. Each phase features its own properties, which can be contributed to the composites. This review paper provides an overview of ceramic tools for machining nickel-based superalloys including the effect of cutting parameters, use of coolant supply, and the integrity of the machined surface. Special emphasis is placed on SiAlON ceramic as the currently most promising candidate for the processing of these alloys.

\section{Type of Tool Materials for Machining Nickel-Based Alloys}

Based on the analysis of publication activity over the last 20-30 years, it is worth noting that there is a growing interest within the scientific community regarding the use of effective solutions for the treatment of heat-resistant nickel-based alloys [88-103]. Improving efficiency basically entails improving cutting conditions (cutting speed, feed) without losing the quality of the machined surface. Since this review emphasises material categories, Figure 1 shows three groups of tool materials that are usually applicable for processing Ni-based alloys [104-122]. 


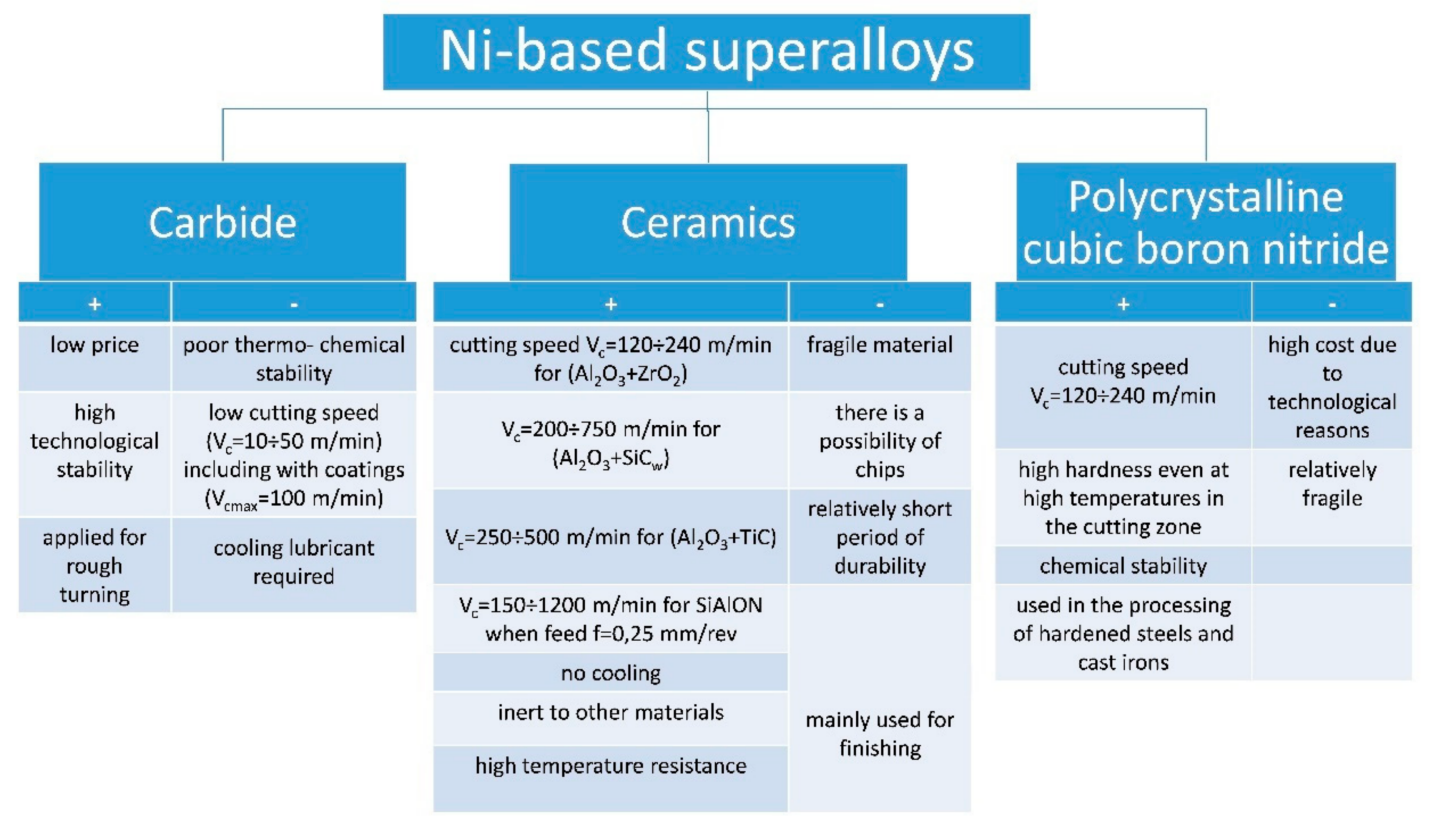

Figure 1. Material categories in the machining of Ni-based superalloys.

Next, the details of each are discussed.

\subsection{Carbide for Machining Nickel-Based Alloys}

The use of carbide as a cutting tool in the processing of nickel-based heat resistant super alloys (HRSA) was due to their high ratio of hardness, tensile strength, and fracture toughness [123]. It should be noted that the basic research of physical and mechanical, chemical, and operational processing conditions of carbide instruments during turning and milling of various structural materials, including also machining of hard materials, began from the 1970s to the 1980s of the previous century [108,124]. Koseki et al. [125] performed a comprehensive analysis of damage analysis of carbide instruments with commercial TiN PVD-coated at turning Ni-based superalloy (Inconel 718) [118]. Electron probe microanalysis (EPMA), scanning electron microscopy (SEM), and transmission electron microscopy (TEM) analyses showed that the treated material mechanically adheres to the tool, but there are no chemical bonds. These facts confirm the absence of diffusive and oxidative deterioration. The authors highlighted the development of extended wear in places of micro-defects in the form of pores and voids in the coating. Thus, it is necessary to minimise such defects. Hu et al. [126] suggested using the rake face chemical-mechanical polishing (CMP) to improve the cutting performance and the tool life. The study showed that in turning GH4169 nickel-based superalloy, this method made it possible to reduce the components of the cutting forces $\mathrm{F}_{\mathrm{x}}, \mathrm{F}_{\mathrm{y}}$, and $\mathrm{F}_{\mathrm{z}}$ by $18.26 \%, 11.37 \%$ and $13.81 \%$, respectively, and the service life compared to the insert without processing by $35.92 \%$. Currently, the main vector of the development of carbide instruments is aimed at using complexstructured, multifunctional, wear-resistant coatings [127-129]. Vereschaka et al. [127] noted that the architecture of multilayer wear-resistant coatings should be designed based on the properties of the material being processed. First, an intermediate high-adhesion layer must be applied, followed by functional layers, which make it possible to resist abrasive and diffusion wear during the turning process. It is also worth noting that these studies on the use of carbide tools for machining nickel-based HRSA have not been interrupted and are being carried out at the present time, making it possible to use this tool as the main material in the industry. Despite the low cost of carbide tools, they are generally employed at relatively low cutting speeds $(\sim 50-80 \mathrm{~m} / \mathrm{min})$, because they cannot withstand the high temperature and stresses in the cutting zone encountered during machining. Therefore, 
other classes of ceramics are needed for machining nickel-based HRSA alloys, which will be discussed in the following sections.

\subsection{Cubic Boron Nitride for Machining Nickel-Based Alloys}

One such material is cubic boron nitride (CBN), which is the second hardest of all known materials and has received significant attention as a material for cutting tools. Costes et al. [113] proposed using cubic boron nitride instead of carbide as a cutting tool for the machining of Inconel 718. It was noted that the main causes of tool wear in processing CBN nickel alloys are adhesion and diffusion, due to their chemical affinity and conventional abrasion. The formation of wear along the front surface was observed, as well as uneven wear along the front surface in the form of a dimple, caused by thermal effects from the edge to the centre. Arunachalam et al. [130] indicated, that in the process of turning nickelbased alloy, diffusion of $\mathrm{Nb}, \mathrm{Cr}, \mathrm{Fe}$, and $\mathrm{Ni}$ from the workpiece into the tool occurs. Mutual diffusion was observed not in the entire volume of the material but in specific areas, which allowed them to conclude that certain conditions were created during the cutting process, in which the chemical reaction between the tool and the processed materials was minimal. In their study, Harris et al. [131] aimed to find a relationship between the CBN content, the TiC/TiN bonding phases, the grain size $(1-15 \mu \mathrm{m})$, and the physical and mechanical properties of the tool (hardness/temperature) using Vickers indentation method as an evaluation tool by heating under various conditions. Kaya et al. [132] conducted a study of the development of wear of polycrystalline diamond (PCD) and cubic boron nitride (CBN) tools during high-speed (cutting speed $\mathrm{Vc}=70-250 \mathrm{~m} / \mathrm{min}$ ) turning of NiTi alloys. It was found that both tool materials are sensitive to increased cutting speed. At cutting speeds up to $\mathrm{Vc}=130 \mathrm{~m} / \mathrm{min}$, the dominant wear is adhesion wear and abrasion along the insert main flank surface caused by mechanical stress. With an increase in the cutting speed, thermal effects, mainly spalling of grains from pressure on the front surface were observed, thus resulting in the observed diffusion, chemical, and oxidative types of wear, leading to premature failure of the CBN. This study allows us to conclude that there is a limited increase in cutting speed due to the physical and mechanical characteristics of CBN.

Based on literature data, it should be noted that these tools are used to machine nickel-base alloys of hardness equal to or greater than $340 \mathrm{HV}$. The recommended speed range of these tools to machine Inconel 718 is from 120 to $240 \mathrm{~m} \cdot \mathrm{min}^{-1}$. However, the manufacturing process of the CBN cutting tool is an extremely difficult, expensive, and time-consuming task.

\subsection{Ceramic Instruments for Machining Nickel-Based Superalloys}

In the processing of difficult-to-machine steels and alloys, ceramic tool materials are slowly replacing hard alloys due to their physical and chemical properties [3]. Ceramic tools are used for a wide range of operations and materials, including high-speed finishing of high-temperature alloys. The specific properties of nickel-based heat-resistant alloys when properly used can provide high productivity. The variety of grades of ceramic instruments and compositions appearing on the market every year makes it possible to assert the promise and interest in the material. Currently, ceramic cutting tools (ceramic inserts) are mainly represented by NTK Cutting Tools (USA), NikkoTools (Italy), Sandvik Coromant (Sweden), ISCAR (Israel), Tungaloy Corporation (Japan), CeramTec (Germany), etc. Silicon nitride- and alumina-based ceramics are particularly highlighted in the processing of Nibased superalloys. Zhao [133] identified four groups of instrumental materials in his work: $\mathrm{Al}_{2} \mathrm{O}_{3}$-based ceramics, $\mathrm{Si}_{3} \mathrm{~N}_{4}$-based ceramics, $\mathrm{SiAlON}$-based ceramics, and ceramic matrix composites. He noted the growing need for ceramic instruments and highlighted the stages of development from 1938 to the present day. One of the most promising ceramic materials for efficient turning Nickel-Based HRSA is $\mathrm{Al}_{2} \mathrm{O}_{3}$ with the addition of TiC and other hard particles such as $\mathrm{TiN},(\mathrm{W}, \mathrm{Ti}) \mathrm{C}, \mathrm{Ti}(\mathrm{C}, \mathrm{N}), \mathrm{TiB}_{2}$, and $\mathrm{SiCw}[134,135]$.

Table 2 presents various categories, compositions, and properties of $\mathrm{Al}_{2} \mathrm{O}_{3}$-based ceramic instruments for turning hardened steels and heat-resistant alloys. 
Table 2. Various categories, compositions, and properties of $\mathrm{Al}_{2} \mathrm{O}_{3}$-based ceramic instruments for turning hardened steels and heat-resistant alloys.

\begin{tabular}{|c|c|c|c|c|c|c|c|}
\hline Composite & Producer/Country & Grade & $\begin{array}{l}\text { Density } \\
\left(\mathrm{g} \cdot \mathrm{cm}^{3}\right)\end{array}$ & Hardness (HRA) & $\begin{array}{c}\text { Flexural } \\
\text { Strength } \\
\text { (MPa) }\end{array}$ & $\begin{array}{c}\text { Fracture } \\
\text { Toughness } \\
\left(\mathrm{MPa} \cdot \mathrm{m}^{1 / 2}\right)\end{array}$ & Applications \\
\hline \multirow{4}{*}{$\mathrm{Al}_{2} \mathrm{O}_{3} /(\mathrm{W}, \mathrm{Ti}) \mathrm{C}$} & Shandong University (China) & AT & 4.6 & $2040 \mathrm{HV}$ & 820 & 7.4 & \multirow{4}{*}{$\begin{array}{c}\text { Machining } \\
\text { hardened steels }\end{array}$} \\
\hline & & SG-4 & 6.65 & $94.7-95.3$ & 850 & 4.94 & \\
\hline & & FG-2(graded) & & $94.7-95.5$ & 830 & & \\
\hline & & AWT10 & 6.65 & $2350 \mathrm{HV}$ & 930 & 7.55 & \\
\hline $\mathrm{Al}_{2} \mathrm{O}_{3} / \mathrm{WC} / \mathrm{TiC}_{\mathrm{n}}$ & Shandong University (China) & LWT-1 & 6.5 & $2340 \mathrm{HV}$ & 840 & 7.87 & \\
\hline \multirow{3}{*}{$\mathrm{Al}_{2} \mathrm{O}_{3} / \mathrm{SiC}_{\mathrm{w}}$} & Shandong University (China) & $\mathrm{JX}-1$ & 3.63 & $94-95$ & 800 & 8.5 & \multirow{3}{*}{$\begin{array}{l}\text { Machining heat } \\
\text { resistant alloys }\end{array}$} \\
\hline & Sandvik Coromant (Sweden) & CC670 & 3.74 & $2000 \mathrm{HV}$ & 900 & 8.0 & \\
\hline & Kennametal (USA) & KY4300 & 3.74 & $2000 \mathrm{HV}$ & 700 & 7.7 & \\
\hline $\mathrm{Al}_{2} \mathrm{O}_{3} / \mathrm{TiB}_{2} / \mathrm{SiC}_{\mathrm{W}}$ & Shandong University (China) & LP-2 & 3.94 & $94-95$ & $700-800$ & 7.8 & \\
\hline
\end{tabular}

Usually, $\mathrm{Al}_{2} \mathrm{O}_{3}$ /carbide or $\mathrm{Al}_{2} \mathrm{O}_{3} /$ nitride composite grades are selected for machining ferrous metals (such as steels and cast irons) at high cutting speeds. This is because of their hardness, wear and heat resistance, chemical stability, as well as their ability to achieve a high level of accuracy and finish. Interrupted cuts are only recommended with very small chip sections and strong cutting-edge designs, as found in round or square inserts with T-lands. $\mathrm{Al}_{2} \mathrm{O}_{3} / \mathrm{SiC}_{(\mathrm{w})}$ composite grades are used for machining heat-resistant alloys, such as those which are nickel based, in virtue of their increased resistance to fracturing. by adding micro-sized $\mathrm{WC}$ and nano-sized TiC particles into the micro-sized $\mathrm{Al}_{2} \mathrm{O}_{3}$ matrix, $\mathrm{Al}_{2} \mathrm{O}_{3} / \mathrm{WC} / \mathrm{TiCn}$ micro-nanocomposite ceramic tool material LWT-1 (Table 2) was developed at Shandong University. This was achieved through the use of the hot-pressing technique [135]. To prevent the formation of agglomerative TiC nanoparticles (average grain size of $140 \mathrm{~nm}$ ), the surfactant polyethylene glycol (PEG) and deionised water were used as a dispersant and dispersing medium, respectively. This was carried out with the aim of obtaining a well reagglomerated and uniform suspension of $\mathrm{TiC}$ nanoparticles. These particles were then mixed with micro $\mathrm{Al}_{2} \mathrm{O}_{3}$ (average grain size of $0.5 \mu \mathrm{m}$ ), WC powder (average grain size of $0.4 \mu \mathrm{m}$ ), and the sintering additives $\mathrm{MgO}$ and $\mathrm{NiO}$. The mixed slurry was ball milled for $48 \mathrm{~h}$ and then dried at $330{ }^{\circ} \mathrm{C}$ in a vacuum. The powder mixture was sieved through a 120-mesh sieve and loaded into a cylindrical graphite die with an inner diameter of $42 \mathrm{~mm}$. The specimens were then sintered via the hot-pressing technique with flowing $\mathrm{N}_{2}$ at a temperature of $1700{ }^{\circ} \mathrm{C}$ for $10 \mathrm{~min}$ under a fixed uniaxial pressure of $30 \mathrm{MPa}$. Grade AWT10 (Table 2) is another micro-nanocomposite ceramic tool material that was hot-pressed by adding micro-sized (W,Ti)C and nano-sized $\mathrm{Al}_{2} \mathrm{O}_{3}$ particles into a micro-sized $\mathrm{Al}_{2} \mathrm{O}_{3}$ matrix [135]. In their review, Xikun et al. highlighted a line of commercial and experimental $\mathrm{Si}_{3} \mathrm{~N}_{4}$-based ceramic instruments for processing difficult-to-machine alloys due to their high thermal resistance, high thermal conductivity, low coefficient of thermal expansion, and fracture toughness. There has been a great success in toughening research and application of cutting tool materials with $\mathrm{Si}_{3} \mathrm{~N}_{4}$ as raw materials, $\mathrm{Y}_{2} \mathrm{O}_{3}, \mathrm{Al}_{2} \mathrm{O}_{3}, \mathrm{MgO}, \mathrm{ZrO}_{2}, \mathrm{HfO}_{2}$, as sintering additives, additives of carbide strengthening phase, or $\mathrm{SiC}_{\mathrm{w}}, \mathrm{SiC}_{\mathrm{p}}$ (Table 3) $[115,133]$. 
Table 3. Various categories, compositions, and properties of $\mathrm{Si}_{3} \mathrm{~N}_{4}$-based ceramic instruments.

\begin{tabular}{|c|c|c|c|c|c|c|}
\hline Brand & Composition & Hardness (HRA) & $\begin{array}{c}\text { Bending Strength } \\
\text { (GPa) }\end{array}$ & $\begin{array}{l}\text { Density } \\
\left(\mathrm{g} \cdot \mathrm{cm}^{3}\right)\end{array}$ & $\begin{array}{l}\text { Fracture Toughness } \\
\left(\mathrm{MPa} \cdot \mathrm{m}^{1 / 2}\right)\end{array}$ & Company/Country \\
\hline HDM1 & $\mathrm{Si}_{3} \mathrm{~N}_{4}$ matrix & 92.5 & 0.93 & & & China \\
\hline HDM2 & $\mathrm{Si}_{3} \mathrm{~N}_{4}$ matrix, fiber & 93 & 0.98 & & & \\
\hline HDM3 & $\mathrm{Si}_{3} \mathrm{~N}_{4}$ matrix & 92.5 & 0.83 & & & \\
\hline N55555 & $\mathrm{Si}_{3} \mathrm{~N}_{4}$ matrix & $(\geq 96.5)$ & & & & \\
\hline CC680 & $\mathrm{Si}_{3} \mathrm{~N}_{4}-\mathrm{Al}_{2} \mathrm{O}_{3}-\mathrm{Y}_{2} \mathrm{O}_{3}$ & $93.5 \sim 94.5$ & $1.0 \sim 1.3$ & & & $\begin{array}{l}\text { Sandvik Coromant } \\
\text { (Sweden) }\end{array}$ \\
\hline KY3000 & $\begin{array}{c}77 \% \mathrm{Si}_{3} \mathrm{~N}_{4}-13 \% \\
\mathrm{Al}_{2} \mathrm{O}_{3}-10 \% \mathrm{Y}_{2} \mathrm{O}_{3}\end{array}$ & 1800 (uniaxial HV) & $1.0 \sim 1.3$ & & & Kennametal (USA) \\
\hline Kyon2000 & No pressure sintered Sialon & $1800(\mathrm{HV})$ & 765 & $3.2 \sim 3.4$ & 6.5 & USA \\
\hline Quantum5000 & Hot pressing $\mathrm{Si}_{3} \mathrm{~N}_{4}-\mathrm{TiC}$ & 93.5 & 750 & 3.4 & 4.3 & \\
\hline Lsay & Hot pressing $\mathrm{Si}_{3} \mathrm{~N}_{4}+\mathrm{Y}_{2} \mathrm{O}_{3}$ & $2150(\mathrm{HV})$ & 714 & 3.2 & & \\
\hline SX7 & & 93.0 & 1100 & & 7.0 & Japan \\
\hline FX920 & & 92.8 & 960 & 3.27 & 9.4 & \\
\hline FX910 & & 94.7 & 760 & 3.32 & 6.7 & \\
\hline Naycon & & 92.8 & 1000 & 3.23 & & \\
\hline NCT & Hot pressing $\mathrm{Si}_{3} \mathrm{~N}_{4}$ & 92.6 & 816 & 3.3 & 6.7 & Germany \\
\hline KY1540 & $\alpha / \beta-$ SiAlON & 18.24 & & 3.35 & 7.45 & Kennametal (USA) \\
\hline
\end{tabular}

\section{Features of SiAlONs and Their Application in the Processing of Nickel- \\ Based HRSA}

It is known that nickel alloys are very difficult to cut materials due to the high chemical affinity and poor thermal conductivity that they have, in conjunction with the presence of hard-abrasive carbides in their microstructure and the work-hardening that occurs during machining. For this reason, in order to carry out efficient machining of this type of alloy, it is necessary to select the appropriate cutting tool and define the most optimal machining parameters for the tool-part pairs. In mass production, the use of high-speed machining is essential. Unfortunately, this type of machining for nickel alloys using cemented carbide is not feasible due to the loss of the characteristics of the cutting tool mainly related to the ultra-high local temperature that occurs in the tool-part contact zone, which leads to a reduction in the useful life of the tool. One of the ways to avoid the negative effects (high temperature and stresses in the cutting zone) that occur by machining nickel alloys at high cutting speeds $\left(\mathrm{V}=200-750 \mathrm{~m} \cdot \mathrm{min}^{-1}\right.$ ) is the use of ceramic cutting tools, which can keep its properties (chemical stability, hardness, thermal shock resistance, and high wear resistance) for a long time even at high temperatures. The silicon nitride $\left(\mathrm{Si}_{3} \mathrm{~N}_{4}\right)$-based ceramic known as $\mathrm{SiAlON}$ has better thermal properties and toughness than $\mathrm{Al}_{2} \mathrm{O}_{3}$ and is used widely to machine superalloys. SiAlON cutting tools have some special features such as good fracture toughness, hardness (even at high temperatures), and resistance to sudden temperature changes, which make it a suitable material for machining various difficult-to-cut materials including nickel alloys. SixAlxOxNx is characterised by high chemical inertness and low coefficient of thermal expansion; therefore, during cutting, there is more uniform and predictable wear, without grooves and chipping. There are several kinds of SiAlON ceramics, such as $\alpha$-SiAlON, $\beta$-SiAlON, and their combination $(\alpha+\beta)$. The most commonly used compositions at present are $\beta$-SiAlON and $(\alpha+\beta)$ SiAlONs, which contain a substantial excess of sintering aids. However, the field is still changing with compositions developing to suit specific applications.

\section{1. $\alpha$-SiAlON}

$\alpha$-SiAlONs are isostructural with $\alpha-\mathrm{Si}_{3} \mathrm{~N}_{4}$ in which chemical binding of $\mathrm{m}$ and $\mathrm{n}(\mathrm{Si}-\mathrm{N})$ are substituted by Al-N (m) and Al-O (n) bonds, respectively, the schematic diagram of which is shown in Figure 2 [136-138]. In addition, supplementary cation for the stability of crystal lattice of $\alpha$-SiAlONs is needed. 


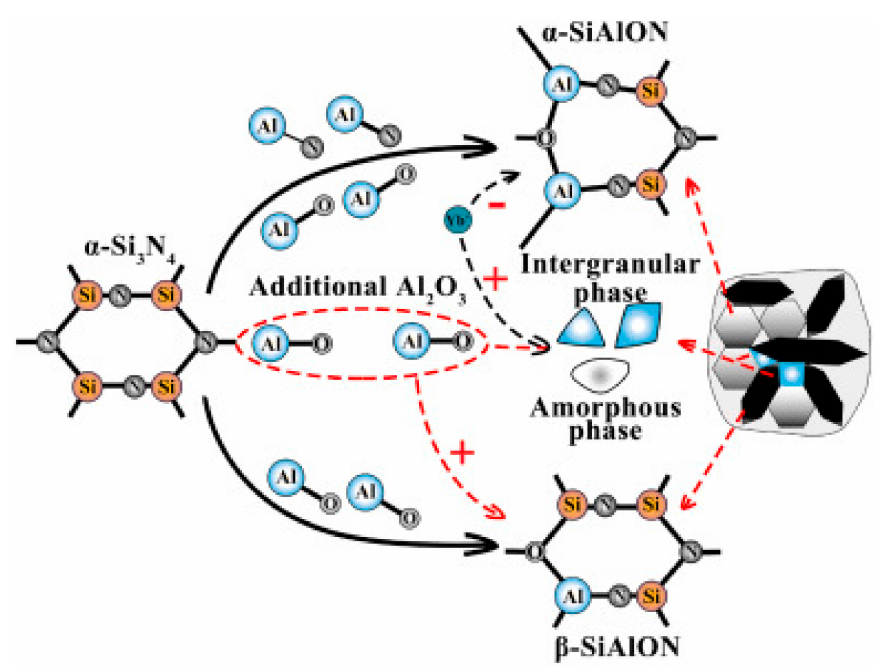

Figure 2. Schematic diagram of the effect of additional $\mathrm{Al}_{2} \mathrm{O}_{3}$ on the phase formation, reproduced from [136], with permission of Elsevier 2013.

$\alpha$-Sialons can be presented by the chemical formula $M_{x}^{v+} \operatorname{Si}_{12-m-n} A_{m+n} O_{n} N_{16-n}$, where $\mathrm{Li}, \mathrm{Mg}, \mathrm{Ca}, \mathrm{Y}$, and/or a rare earth element refer to $\mathrm{M}$, and by considering its ionic radius [138] or with using quenching. For entry of cations with considerable size in structure, the presence of other cations is required. At high temperatures, the $\alpha$-phase, specifically with high $\mathrm{x}$ ( $\mathrm{x}$ is typically between 0.3 and 1.0) is stable, but during the thermal processing, it can transform to $\beta$-phase sialon or other crystalline or glassy phases. The $\alpha$-SiAlONs is used due to its high hardness and temperature resistance due to a decrease in the amount of the residual glassy phase, but for the same reasons, these materials have increased fragility, which requires the introduction of materials with improved fracture toughness but without a significant decrease in hardness [139-143]. In his study, Ekström [144] carried out a series of experiments with $\alpha-\mathrm{SiAlON}$, from which a number of conclusions can be drawn as follows:

1. $\alpha$-SiAlON can be used as a base in a composite material with the addition of silicon carbide or molybdenum-disilicide-reinforcing fibres, which have sufficient chemical compatibility. However, with the introduction of $\mathrm{SiC}_{\mathrm{w}}$, it was not possible to increase the strength, and with the addition of $\mathrm{MoSi}_{2}$, a sharp drop in hardness is observed, which is unacceptable.

2. It was found that it is impossible to use rare earth elements with large ion sizes (for example, $\mathrm{Sm}$, and $\mathrm{Nd}$ ) as a stabiliser of $\alpha$-phases in ceramics used at temperatures above $1000{ }^{\circ} \mathrm{C}$ since they decompose. However, these types of ceramics can be used at low temperatures.

3. The most favourable alloying elements, from the point of view of stability at high temperatures, are rare earth elements with small ion sizes, such as yttrium or ytterbium, which form $\alpha$-phases.

In order to prolong the useful life of the $\alpha$-SiAlON-based cutting tool, different works have been developed based on the addition of different phases to the ceramic structure. For example, Salamon et al. and Rosenflanz et al. [145-147] used $\alpha$-SiAlON with other second phases additives to design new ceramic instruments, which provide a significant enhancement in the mechanical behaviour and chemical stability. All starting powders were homogenised in water (using the buffer) and freeze granulated and biaxially pressed. Heating regimes were carried out in the HIP furnace at $1760^{\circ} \mathrm{C}$ for $1 \mathrm{~h}$ in $\approx 100 \mathrm{MPa} \operatorname{Ar}\left(\mathrm{N}_{2}\right)$. Different heating and cooling rates were applied to obtain different phase compositions from the same starting powders. Heating regimes are labelled as HIP 1 (fastest cooling rate) and HIP 5 (slowest cooling rate). Table 4 shows the chemical compositions studied in this work. 
Table 4. Chemical compositions obtained in [145].

\begin{tabular}{cccc}
\hline Number & Sample & Base & \multicolumn{1}{c}{ Phases } \\
\hline 1 & A039-HIP1 & $\alpha$ - sialon & - \\
\hline 2 & A039-HIP1 & $\alpha$-Sialon & $\mathrm{Y}_{2} \mathrm{O}_{3}, \mathrm{La}_{5} \mathrm{Si}_{3} \mathrm{NO}_{12}, \mathrm{Y}_{10} \mathrm{Al}_{2} \mathrm{Si}_{3} \mathrm{O}_{18} \mathrm{~N}_{4}$ \\
\hline 3 & A057-HIP1 & $\alpha$-Sialon & $\mathrm{SiAl}_{6} \mathrm{O}_{2} \mathrm{~N}_{6}, \mathrm{Y}_{2} \mathrm{O}_{3}, \mathrm{La}_{2} \mathrm{O}_{3}$ \\
\hline 4 & A057-HIP3 & $\beta$-Sialon, $\alpha$-Sialon & $\mathrm{SiAl}_{6} \mathrm{O}_{2} \mathrm{~N}_{6}$ \\
\hline 5 & A057-HIP4 & $\alpha$-Sialon & $\mathrm{SiAl}_{6} \mathrm{O}_{2} \mathrm{~N}_{6}$ \\
\hline 6 & B069-HIP3 & $\beta$-Sialon & - \\
\hline 7 & A039-HIP5 & $\beta$-Sialon & $\mathrm{SiAl}_{6} \mathrm{O}_{2} \mathrm{~N}_{6}$ \\
\hline
\end{tabular}

It was found that hardness (HV1) and fracture toughness $\left(\mathrm{K}_{1 \mathrm{C}}\right)$ for $1-5$ compositions are around 20.2 and $6.8 ; 14.2$ and $6.2 ; 17.0$ and $6.7 ; 15.1$ and $6.7 ; 17.7$ and $6.2 ; 14.4$ and $7.0 ; 19.7$ and 6.9 , respectively. With regards to the tool life of studied materials, the best behaviours (longer life) are shown in samples 3,5 and 6 (31.0, 27.5 and $23.3 \mathrm{~min}$, respectively), compared with standard cutting instruments made from $\beta-\mathrm{Si}_{3} \mathrm{~N}_{4}$. The cooling influence was evaluated by comparison of phase composition of sample number 7. It was found that the presence of defects and polytype $21 \mathrm{R}\left(\mathrm{SiAl}_{6} \mathrm{O}_{2} \mathrm{~N}_{6}\right)$ has an adverse impact on cutting behaviour [145]. However, the presence of homogeneity of the microstructure and pure $\alpha$ - and $\beta$-SiAlONs with a good ratio between elongated and submicron grains provide a positive influence on cutting performance. Moreover, it was shown that pure $\alpha$ - or $\beta$-SiAlONs have better cutting performance, compared with $\beta-\mathrm{Si}_{3} \mathrm{~N}_{4}$, and inhomogeneities and polytype $21 \mathrm{R}$ have higher effects on cutting performance than on macro-mechanical properties (HV1, $\mathrm{K}_{1 \mathrm{c}}$ ); it was also assumed that changing cooling parameters also leads to change in the phase composition (1 vs. 7).

\section{2. $\beta$-SiAlON}

$\beta$-Sialon are formed by substituting silicon in the $\beta-\mathrm{Si}_{3} \mathrm{~N}_{4}$ structure by aluminiumprovided valence compensation by replacement equivalent concentration of $\mathrm{N}$ by $\mathrm{O}$. A general formula of $\beta$-SiAlONs is $\mathrm{Si}_{6-\mathrm{z}} \mathrm{Al}_{\mathrm{z}} \mathrm{O}_{\mathrm{z}} \mathrm{N}_{8-\mathrm{z}}$, with $0<\mathrm{z}<4.2$, where $\mathrm{z}$ (Si-N) bonds are replaced by $z$ (Al-O) bonds [147]. $\beta$-SiAlONs are isostructural with $\beta-\mathrm{Si}_{3} \mathrm{~N}_{4}$. $\beta$-SiAlON ceramics are promising materials for applications involving high temperatures, highly corrosive environments, and high mechanical stress because they exhibit high strength retention and high thermal shock resistance at elevated temperatures and good erosion resistance and low creep [148-152]. Compared with $\mathrm{Si}_{3} \mathrm{~N}_{4}, \beta-\mathrm{SiAlON}$ ceramics are easily sintered and fabricated and can be easily combined with other materials to strengthen or improve the properties of ceramics $[153,154]$.

Due to the fact that for consolidation of $\beta$-SiAlON-based ceramic samples with complex geometry and improved mechanical properties ( $\sigma_{\mathrm{f}}$ up to $1000 \mathrm{MPa}$ and $\mathrm{K}_{1 \mathrm{c}} \sim 8 \mathrm{MPa} \cdot \mathrm{m}^{1 / 2}$ ), conventional sintering techniques were possible, this type of ceramic dominated at the initial stage [155]. Based on high mechanical characteristics, recently, the $\beta$-SiAlON has been used even in additive technologies to obtain parts with complex spatial shapes; for instance, Tian et al. [78] used $\mathrm{Si}_{3} \mathrm{~N}_{4}, \mathrm{Al}_{2} \mathrm{O}_{3}$, and AlN particles as raw materials for the design of $\beta$-SiAlON composition with particular base crystalline phases. In this work, materials for performing ceramic specimens with a $\beta$-SiAlON matrix were obtained by stereolithography technology. The manufacturing technology consisted of the following procedures: the green body $\beta$-SiAlON with other SiAlON phases were degreased and then sintered under the following technological modes: working medium-inert gas, sintering temperature $\mathrm{T}=1800{ }^{\circ} \mathrm{C}$, holding time $1 \mathrm{~h}$, pressure $\mathrm{P}=3 \mathrm{GPa}$. Moreover, the authors studied the effects of the different $\mathrm{Al}_{2} \mathrm{O}_{3}$ contents on shrinkage loss, phase composition, relative density, microstructure, mechanical property, and hardness. XRD methods have shown that the major phase of the ceramics was $\beta-\mathrm{SiAlON}$, and the other phase impurities of it were $\mathrm{Si}_{5} \mathrm{AlON}_{7}, \mathrm{Si}_{3 \cdot 1} \mathrm{Al}_{2 \cdot 9} \mathrm{O}_{2 \cdot 9} \mathrm{~N}_{5 \cdot 1}$, and $\mathrm{Si}_{2} \mathrm{Al}_{4} \mathrm{O}_{4} \mathrm{~N}_{4}$, with mainly intergranular phases 
of $\mathrm{Y}_{3} \mathrm{Al}_{5} \mathrm{O}_{12}, \mathrm{YAlO}_{3}$, and $\mathrm{Al}_{2} \mathrm{O}_{3}$. The sintered $\beta-\mathrm{Si}_{5} \mathrm{AlON}_{7}$ ceramics had a relative density within the order of 90 percent, with Vickers hardness $\left(\mathrm{HV}_{5}=16.7 \mathrm{GPa}\right)$ bending strength $\mathrm{G}_{\mathrm{f}}=465 \mathrm{MPa}$ and fracture toughness $\mathrm{K}_{1 \mathrm{C}}=4.84 \mathrm{MPa} \cdot \mathrm{m}^{1 / 2}$. In addition, Zhuo et al. [156] found that the shrinkage of the material was 28.7 percent. The highest values of fracture toughness at ambient temperature were observed for dense $\beta$-SiAlON ceramic with low $\mathrm{z}$ values $(\mathrm{z} \sim 1)$ and microstructures consisting of elongated crystals and grain boundary glass. However, the hardness values (14-15 GPa) were found relatively low due to the presence of the residual grain boundary glass ( 10 GPa) [157]. Therefore, in cutting tools, $\beta-\mathrm{SiAlON}$ is used as a reinforced phase that provides strength and toughness.

\section{3. $(\alpha+\beta)$ SiAlON}

The $\alpha-\beta$ SiAlON combinations with a minimum of glassy phase are currently the most promising materials for further use, both at low and high temperatures [2]. Figure 3 shows microstructure of as-sintered $\alpha / \beta$-SiAlON composite.
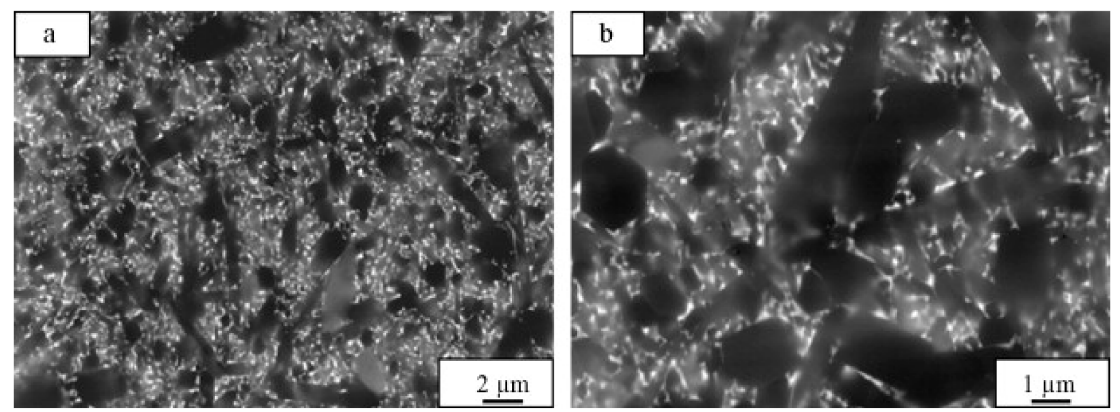

Figure 3. Back-scattered SEM images of as-sintered $\alpha / \beta$-SiAlON composite (a) $10,000 \times$ and (b) $20,000 \times$.

At the same time, $\alpha$-SiAlON ceramic with equiaxed structure exhibits outstanding values of hardness ( 22 GPa), compared to any other sialon ceramic. By varying the ratio of the $\alpha$ - and $\beta$-phases in the raw material mixture, it is also possible to optimise the characteristics of the $\alpha / \beta$-SiAlON mixed ceramics, where $\alpha$ - and $\beta$-phases give high hardness and high-strength toughness, respectively [158]. Moreover, the strength, wear behaviour, and creep resistance of this ceramic can be significantly improved due to the low content of intergranular glass in produced details [157]. Ekström [144] noted that the most favourable ratio of $\alpha-\beta$ phases is approximately 1: 1 . This $\alpha-\beta$ SiAlON ratio allows achieving high hardness $\mathrm{HV}_{10}=22 \mathrm{GPa}$ and sufficient indentation fracture toughness $\mathrm{K}_{1 \mathrm{C}}=5.5 \mathrm{MPa} \cdot \mathrm{m}^{1 / 2}$. Due to the excellent properties of $(\alpha+\beta)$-SiAlONs, they are used in the production of cutting tools. For example, Mandal et al. [159] developed $(\alpha+\beta)$-SiAlON ceramics, which were fabricated in an aquatic environment using various oxides as additives to obtain the dense samples. Then, cast iron and superalloy were machined using sintered samples and commercially available ceramic inserts by turning and milling operations. It was found that the sintered $(\alpha+\beta)$-SiAlONs show a hardness value of about $19 \mathrm{GPa}$, while the values of commercial $\mathrm{Si}_{3} \mathrm{~N}_{4}$ inserts are 15-16 GPa. Therefore, the authors argue that careful selection of starting composition with sintering additives and mixing technique allows the production of $(\alpha+\beta)$-SiAlON ceramic that can be used in machining. Bitterlich et al. [160] introduced, for the first time, particles of $\mathrm{SiC}, \mathrm{WC}, \mathrm{MoSi}_{2}$, and $\mathrm{Ti}(\mathrm{C}, \mathrm{N})$ into the composition of $(\alpha+\beta)$-SiAlON composites to use the material as a cutting tool. The authors noted an unsatisfactory result; however, points of growth of further optimisation of the composition are given in the work. The $(\alpha+\beta)$-SiAlON composites with different reinforcing particles $\left(\mathrm{SiC}, \mathrm{Ti}(\mathrm{C} 30 \mathrm{~N} 70), \mathrm{MoSi}_{2}, \mathrm{WC}\right)$ were prepared by gas pressure sintering. After sintering the new composite material, diffusion of $\mathrm{MoSi}_{2}$ and $\mathrm{WC}$ with the matrix appeared, leading to a change in the composition of the reinforcing phase, which affected 
their properties. The best tribological parameters were obtained for the material with 10 vol. $\%$ SiCw.

\subsection{SiAlON Application in Machining Nickel-Based Alloys}

Due to the physical and mechanical properties of SiAlONs used as cutting tools, their use in the processing of nickel alloys is very widespread. Much research has been conducted to determine the effectiveness of sialon application, compared to other ceramics [159-161]. For instance, Krebs et al. [162] investigated the use of ceramic tools whisker-reinforced SiAlON when turning on the clad alloy steel AISI 6254130 via an automatic system for cladding a tungsten inert gas (TIG). It has been experimentally established that the use of cutting inserts from SiAlON for rough turning of clad alloy 625 is very effective. The use of corundum ceramics $\left(\mathrm{Al}_{2} \mathrm{O}_{3}\right)$ reinforced with whiskers $\left(\mathrm{SiC}_{\mathrm{W}}\right)$ under the same conditions is ineffective [162]. The application of SiAlON inserts contributes to an increase in the removal rate of the work material when compared with the possibilities of using a carbide tool, including those with wear-resistant coatings. It should be noted that the kinetics of wear of SiAlON inserts was identical in a fairly wide range of technological parameters [163-165]. It was noted that most of the wear was formed uniformly over the main surface with the formation of a V-shaped groove with a notch. When turning with low cutting speed limits $(\mathrm{Vc}=140 \mathrm{~m} / \mathrm{min})$, the most intense diffusion wear was observed along the main flank surface, which contributed to the formation of burrs on the workpiece surface. The optimal turning mode was achieved at $V_{c}=160 \mathrm{~m} / \mathrm{min}$ and a feed rate of $0.25 \mathrm{~mm} / \mathrm{rev}$. In addition, it was noted that prolonged turning with worn inserts led to microstructural changes in the processed material and the formation of defects in the form of cavities. Lima et al. [166] conducted a study on turning a nickel-based superalloy Inconel 751 using argon and oxygen atmospheres. Three groups of materials were used as cutting tools: SiAlON $\left(\mathrm{Si}_{3} \mathrm{~N}_{4}+\mathrm{Al}_{2} \mathrm{O}_{3}\right)$, whisker $\left(\mathrm{Al}_{2} \mathrm{O}_{3}+\mathrm{SiCw}\right)$, and mixed $\left(\mathrm{Al}_{2} \mathrm{O}_{3}+\mathrm{TiC}\right)$. Experiments have shown that cutting speed, tool geometry, and cutting fluid affect the type of wear and tool life. However, the best results have been achieved with SiAlON tools. Zheng et al. [81] investigated the wear mechanisms of a Sialon ceramic tool in ultra-high-speed turning Inconel 718. The main wear mechanisms identified in the experimental part were adhesive and mechanical wear. SEM and EDS, during critical wear on the inserts' edge, deposits in the form of separate elements $\mathrm{Ni}, \mathrm{Fe}$, and $\mathrm{Cr}$ were found, contributing to the more active development of wear. The author also noted a serrated morphology shaving, indicating that thermal deformation during the cutting process. Li et al. [167] determined in their work the optimal cutting speed when processing Inconel 718, at which there are no diffusion phenomena that contribute to the formation of cuts on the back surface and craters on the front surface. Nalbant et al. [168] studied the wear mechanisms of SiAlON tools when machining a nickel alloy with plates having different geometric shapes (RNGN 120700, and SNGN 120712). Practice has shown that the predominant failures of square plates are crater wear along the front surface and mechanical wear along the rear surface, while for round plates, it is the formation of notches and mechanical wear on the rear surface. The authors explain this by the fact that round inserts allow the use of different plunge angles, depending on the processing modes. This allows piercing and notching to be controlled. Zheng et al. [169] proposed a new composition of SiAlON tools, strengthening it by introducing graded nano- $\alpha-\mathrm{Si}_{3} \mathrm{~N}_{4}$ into its composition. The experimental material made it possible to reduce the coefficient of friction and reduce the adhesive reactions. Mechanical tests showed that the introduction of $\alpha-\mathrm{Si}_{3} \mathrm{~N}_{4}$ made it possible to reduce microcracks on the working parts of the inserts, which made it possible to increase the cutting speed up to $300 \mathrm{~m} / \mathrm{min}$. Shalaby et al. [63] used SiAlON ceramic tools in the processing of aerospace superalloy Inconel 100 (IN100). The effect of cutting speed on chip formation in dry finish turning was investigated. It is noted in the work that a change in cutting speeds, in a certain range, leads to the formation of various lubricating and protective tribofilms that contribute to the elimination of the development of micro-cracks and defects. 


\section{Conclusions}

Different types of cutting tools with diverse characteristics are now being used in the industry for hard machining. Carbides are the most commonly used tool materials in the machining of Ni-based superalloys currently, owing to their excellent balance between cost and performance. However, the recommended cutting speeds range from 10 to $30 \mathrm{~m} \cdot \mathrm{min}^{-1}$ when machining nickel-based alloys with these tools. Higher speed is not recommended due to the loss of the characteristics of cutting tools, mainly related to the ultra-high local temperature that occurs in the tool-part contact zone, which leads to a reduction in the tool life [170-172]. Cubic boron nitride cutting tools appear to give better overall performance than cemented carbides when machining nickel-based alloys. Amongst all known materials, its hardness is second only to that of diamonds. It has excellent wear durability, high hot hardness, good thermal resistance a high coefficient of thermal conductivity. However, its tool cracking, due to its high brittleness, and chip breaking difficulty, owing to no chip breaker, are the two major issues of a CBN cutting tool. Moreover, the cost of CBN tools does, however, place a strict limitation on their use. Polycrystalline diamond tools demonstrate wear resistance almost 500 times greater than those of tungsten carbide and extreme hardness. On the other hand, PCD tools are extremely fragile and exhibit low toughness. SiAlON cutting tools were considered as a suitable material for machining a variety of difficult-to-cut materials, including nickel alloys, due to their special characteristics such as good fracture toughness, hardness (even at high temperatures), and resistance to sudden changes in temperature. In addition, the study provided a description of the various types of SiAlON ceramics such as $\alpha-\mathrm{SiAlON}$, $\beta$-SiAlON, and their combinations $(\alpha+\beta)$. Examples of the use of sialons in the processing of nickel-based superalloys were given. The review showed that effective nickel-based HRSA treatment is a pressing issue. The most promising direction of development is the use of progressive methods of introducing alloying elements into the $\mathrm{SiAlON}$ and $\mathrm{Si}_{3} \mathrm{~N}_{4}$ ceramic matrix. It is worth noting that desired material for cutting tools for particular applications is the one that demonstrates a balanced combination of various features such as hardness, toughness, wear resistance, thermal shock resistance, and chemical stability, especially at elevated temperatures. In addition, all related factors as cutting tool failure and geometry, coolant and machining conditions, and cutting chip must be taken into account in the selection of a cutting tool. As is evident throughout this review, the design and development of new tool geometry and new machining method, new tool materials, and functional surfaces remain major driving forces for studies on cutting tool technology in the machining of Ni-based superalloys.

Author Contributions: Conceptualisation, A.S. (Anton Smirnov) and A.S. (Anton Seleznev); data curation, N.W.S.P.; formal analysis, A.S. (Anton Smirnov) and A.S. (Anton Seleznev); funding acquisition, A.S. (Anton Seleznev); investigation, N.W.S.P.; methodology, A.S. (Anton Smirnov) and A.S. (Anton Seleznev); project administration, A.S. (Anton Smirnov) and A.S. (Anton Seleznev); resources, A.S. (Anton Smirnov), A.S. (Anton Seleznev) and N.W.S.P.; supervision, A.S. (Anton Smirnov) and A.S. (Anton Seleznev); visualisation, A.S. (Anton Smirnov) and N.W.S.P.; writingoriginal draft preparation, A.S. (Anton Smirnov). All authors have read and agreed to the published version of the manuscript.

Funding: We would like to thank the Ministry of Science and Higher education of the Russian Federation for supporting this work under Grant Number 20-79-00222.

Institutional Review Board Statement: Not applicable.

Informed Consent Statement: Not applicable.

Data Availability Statement: The data described in this article are openly available in the previous works.

Acknowledgments: The study was carried out on the equipment of the Centre of collective use of MSUT “STANKIN” (project 075-15-2021-695).

Conflicts of Interest: The authors declare no conflict of interest. 


\section{References}

1. Sommitsch, C.; Radis, R.; Krumphals, A.; Stockinger, M.; Grill, D. Microstructure control in processing nickel, titanium and other special alloys. Microstructure evolution in metal forming processes. In Woodhead Publishing Series in Metals and Surface Engineering; Woodhead: Cambridge, UK, 2012; pp. 337-383.

2. Pollock, T.M. Nickel-Based Superalloys for advanced turbine engines. J. Propuls. Power 2006, 22, 361-374. [CrossRef]

3. Richards, N.; Aspinwall, D. Use of ceramic tools for machining nickel-based alloys. Int. J. Mach. Tools Manf. 1989, 10, 575-588. [CrossRef]

4. Nowotnik, A. Nickel-based superalloys. In Reference Module in Materials Science and Materials Engineering; Elsevier: Amsterdam, The Netherlands, 2016; pp. 1-7.

5. Thellaputta, G.R.; Chandra Bose, P.S.; Rao, C.S. Machinability of nickel-based superalloys: A Review. Mat. Today Proc. 2017, 4, 3712-3721. [CrossRef]

6. Ezugwu, E.O.; Bonney, J.; Yamane, Y. An overview of the machinability of aeroengine alloys. J. Mat. Process. Tech. 2003, 134, 233-253. [CrossRef]

7. Pervaiz, S.; Rashid, A.; Deiab, I.; Nicolescu, M. Influence of tool materials on machinability of titanium- and nickel-based alloys: A review. Mat. Manuf. Proc. 2014, 29, 219-252. [CrossRef]

8. Arunachalam, R.M.; Mannan, M.A.; Spowage, A.C. Residual stress and surface roughness when facing age hardened Inconel 718 with cBN and ceramic cutting tools. Int. J. Mach. Tools Manuf. 2004, 44, 879-887. [CrossRef]

9. Arunachalam, R.M.; Mannan, M.A.; Spowage, A.C. Surface integrity when machining age hardened Inconel 718 with coated carbide cutting tools. Int. J. Mach. Tools Manuf. 2004, 44, 1481-1491. [CrossRef]

10. Sharman, A.R.C.; Hughes, J.J.; Ridgway, K. Workpiece surface integrity and tool life issues when turning Inconel 718 nickel-based superalloy. Mach. Sci. Technol. 2004, 8, 399-414. [CrossRef]

11. Sadat, A.B.; Reddy, M.Y.; Wang, B. Plastic deformation analysis in machining of Inconel 718 nickel base superalloy using both experimental and numerical methods. Int. J. Mech. Sci. 1991, 33, 829-842. [CrossRef]

12. Ezugwu, E.O.; Wang, Z.M.; Okeke, C.I. Tool life and surface integrity when machining Inconel 718 with PVD-and CVD-coated tools. Tribology 1999, 42, 353-360. [CrossRef]

13. Schlauer, C.; Peng, R.L.; Oden, M. Residual stresses in a nickel-based superalloy introduced by turning. Mater. Sci. Forum. 2002, 404-407, 173-178. [CrossRef]

14. Sadat, A.B. Surface region damage of machined Inconel 718 nickel base superalloy using natural and controlled contact length tools. Wear 1987, 119, 225-235. [CrossRef]

15. Ezugwu, E.O.; Tang, S.H. Surface abuse when machining cast iron (G-17) and nickel-base superalloy (Inconel 718) with ceramic tools. J. Mater. Process. Technol. 1995, 55, 63-69. [CrossRef]

16. Ulutan, D.; Sima, M.; Özel, T. Prediction of Machining Induced Surface Integrity Using Elastic-Viscoplastic Simulations and Temperature-Dependent Flow Softening Material Models in Titanium and Nickel-Based Alloys. Adv. Mater. Res. 2011, 223, 401-410. [CrossRef]

17. Soo, S.L.; Aspinwall, D.K.; Dewes, R.C. Three-Dimensional, Finite element modelling of high-speed milling of Inconel 718. Proc. Inst. Mech. Eng. B J. Eng. Manuf. 2004, 218, 1555-1561. [CrossRef]

18. Darwish, S.M. The impact of tool material and the cutting parameters on surface roughness of supermet 718 nickel superalloy. J. Mater. Process. Technol. 2000, 97, 10-18. [CrossRef]

19. Aspinwall, D.K.; Soo, S.L.; Berrisford, A.E.; Walder, G. Workpiece surface roughness and integrity after WEDG of Ti-6Al-4V and Inconel 718 using minimum damage generator technology. CIRP Ann.-Manuf. Technol. 2008, 57, 187-190. [CrossRef]

20. Attia, H.; Tavakoli, S.; Vargas, R.; Thomson, V. Laser-Assisted High-Speed Finish Turning of Superalloy Inconel 718 under Dry Conditions. CIRP Ann.-Manuf. Technol. 2010, 59, 83-88. [CrossRef]

21. Axinte, D.; Chiffre, D.L. Effectiveness and resolution of tests for evaluating the performance of cutting fluids in machining aerospace alloys. Ann. CIR 2008, 57, 129-132. [CrossRef]

22. Axinte, D.; Axinte, M.; Tannock, J.D.T. A multicriteria model for cutting fluid evaluation. Proc. Inst. Mech. Eng. Part B 2003, 217, 1341-1353. [CrossRef]

23. Jin, D.; Liu, Z.; Yi, W.; Su, G. Influence of cutting speed on surface integrity for powder metallurgy nickel-based superalloy FGH95. Int. J. Adv. Manuf. Technol. 2011, 56, 553-559. [CrossRef]

24. Jin, D.; Liu, Z. Effect of cutting speed on surface integrity and chip morphology in high-speed machining of PM nickel-based super alloy FGH95. Int. J. Adv. Manuf. Technol. 2012, 60, 893-899. [CrossRef]

25. Jin, D.; Liu, Z. Damage of the machined surface and subsurface in orthogonal milling of FGH95 superalloy. Int. J. Adv. Manuf. Technol. 2013, 68, 1573-1581. [CrossRef]

26. Jin, D.; Shaoyu, L. Deformation-phase transformation coupling mechanism of white layer formation in high speed machining of FGH95 Ni-based superalloys. Appl. Surf. Sci. 2014, 292, 197-203.

27. Veldhuis, S.C.; Dosbaeva, G.K.; Elfizy, A.; Fox-Rabinovich, G.S.; Wagg, T. Investigations of white layer formation during machining of powder metallurgical Nibased ME 16 super alloy. J. Mater. Eng. Perform. 2010, 19, 1031-1036. [CrossRef]

28. Soo, S.L.; Hood, R.; Aspinwall, D.K.; Voice, W.E.; Sage, C. Machinability and surface integrity of RR1000 nickel-based super alloy. CIRP Ann.-Manuf. Technol. 2011, 60, 89-92. [CrossRef] 
29. Herbert, C.R.J.; Kwong, J.; Kong, M.C.; Axinte, D.A.; Hardy, M.C.; Withers, P.J. An evaluation of the evolution of workpiece surface integrity in hole making operations for a nickel-based super alloy. J. Mater. Process. Technol. 2012, 212, $1723-1730$. [CrossRef]

30. Herbert, C.R.J.; Axinte, D.A.; Hardy, M.C.; Brown, P.D. Investigation into the characteristics of white layers produced in a nickel-based super alloy from drilling operations. Mach. Sci. Technol. Int. J. 2012, 16, 40-52. [CrossRef]

31. Kwong, J.; Axinte, D.A.; Withers, P.J.; Hardy, M.C. Minor cutting edge-workpiece interactions in drilling of an advanced nickel-based superalloy. Int. J. Mach. Tools Manuf. 2009, 49, 645-658. [CrossRef]

32. Kwong, J.; Axinte, D.A.; Withers, P.J. The sensitivity of Ni-based superalloy to hole making operations: Influence of process parameters on subsurface damage and residual stress. J. Mater. Process. Technol. 2009, 209, 3968-3977. [CrossRef]

33. Axinte, D.A.; Andrews, P.; Li, W.; Gindy, N.; Withers, P.J. Turning of advanced Ni based alloys obtained via powder metallurgy route. Ann. CIR 2006, 55, 117-120. [CrossRef]

34. Ranganath, S.; Guo, C.; Hegde, P. A finite element modeling approach to predicting white layer formation in nickel superalloys. CIRP Ann.-Manuf. Technol. 2009, 58, 77-80. [CrossRef]

35. Ozel, T.; Arisoy, Y.M. Experimental and Numerical investigations on machining induced surface integrity in Inconel-100 nickel-base alloy. Procedia CIR 2014, 13, 302-307. [CrossRef]

36. Ulutan, D.; Arisoy, Y.M.; Ozel, T.; Mears, L. Empirical modeling of residual stress profile in machining nickel-based superalloys using the sinusoidal decay function. Procedia CIR 2014, 13, 365-370. [CrossRef]

37. Ulutan, D.; Ozel, T. Multi objective optimization of experimental and simulated residual stresses in turning of nickel-alloy IN100. Mater. Manuf. Process. 2013, 28, 835-841. [CrossRef]

38. Joshi, S.V.; Vizhian, S.P.; Sridhar, B.R.; Jayaram, K. Parametric study of machining effect on residual stress and surface roughness of nickel-base super alloy Udimet 720. Adv. Mater. Res. 2008, 47-50, 13-16. [CrossRef]

39. Cui, C.; Gu, Y.; Harada, H.; Sato, A. Microstructure and yield strength of Udimet 720LI alloyed with Co-16.9 Wt Pct Ti. Metall. Mater. Trans. A 2005, 36, 2921-2927.

40. Kitagawa, T.; Kubo, A.; Maekawa, K. Temperature and wear of cutting tools in high-speed machining of Inconel 718 and Ti-6Al-6V-2Sn. Wear 1997, 202, 142-148. [CrossRef]

41. Rahman, M.; Seah, W.K.H.; Teo, T.T. The machinability of Inconel 718. J. Mater. Process. Technol. 1997, 63, 199-204. [CrossRef]

42. Dudzinski, D.; Devillez, A.; Moufki, A.; Larrouquerre, D.; Zerrouki, V.; Vigneau, J. A review of developments towards dry and high speed machining of Inconel 718 alloy. Int. J. Mach. Tools Manuf 2004, 44, 439-456. [CrossRef]

43. Li, L.; He, N.; Wang, M.; Wang, Z.G. High speed cutting of Inconel 718 with coated carbide and ceramic inserts. J. Mater. Process. Technol. 2002, 129, 127-130. [CrossRef]

44. Mitrofanov, A.V.; Babitsky, V.I.; Silberschmidt, V.V. Finite element analysis of ultrasonically assisted turning of Inconel 718. J. Mater. Process. Technol. 2004, 153-154, 233-239. [CrossRef]

45. Zhang, B.; Mynors, D.J.; Mugarra, A.; Ostolaza, K. Representing the superplasticity of Inconel 718. J. Mater. Process. Technol. 2004, 153-154, 694-698. [CrossRef]

46. Uhlmann, E.; von der Schulenburg, M.G.; Zettier, R. Finite element modeling and cutting simulation of Inconel 718. Ann. CIR 2007, 56, 61-64. [CrossRef]

47. Courbon, C.; Kramar, D.; Krajnik, P.; Pusavec, F.; Rech, J.; Kopac, J. Investigation of machining performance in high-pressure jet assisted turning of Inconel 718: Anexperimental study. Int. J. Mach. Tools Manuf. 2009, 49, 1114-1125. [CrossRef]

48. Lu, Y.; Guo, C. Finite element modeling of multi-pass machining of Inconel 718. In Proceedings of the 2009 ASME International Conference on Manufacturing Science and Engineering, Lafayette, IN, USA, 5-7 October 2009; Paper No. 84086.

49. Sunulahpa, R.; Oru, M.; Had, M.; Rimac, M. Optimization of the mechanical properties of the superalloy nimonic 80a. Mater. Tehnologije 2012, 46, 263.

50. Zou, B.; Chen, M.; Huang, C. An study on surface damages caused by turning NiCr20TiAl nickel-based alloy. J. Mater. Process. Technol. 2009, 209, 5802-5809. [CrossRef]

51. Aytekin, H.; Akcin, Y. Characterization of borided Inconel 825 alloy. Mater. Des. 2013, 50, 515-521. [CrossRef]

52. Thakur, A.; Gangopadhyay, S.; Maity, K. Effect of cutting speed and CVD multilayer coating on machinability of Inconel 825. Surf. Eng. 2014, 30, 516-523. [CrossRef]

53. Thakur, A.; Gangopadhyay, S.; Mohanty, A. Investigation on Some Machinability Aspects of Inconel 825 during Dry Turning. Mater. Manuf. Process. 2014, 30, 1026-1034. [CrossRef]

54. Thakur, A.; Mohanty, A.; Gangopadhyay, S. Comparative study of surface integrity aspects of Incoloy 825 during machining with uncoated and CVD multilayer coated inserts. Appl. Surf. Sci. 2014, 320, 829-837. [CrossRef]

55. Ezilarasan, C.; Kumar, V.S.; Velayudham, A. An experimental analysis and measurement of process performances in machining of Nimonic C-263 super alloy. Measurement 2013, 46, 185-199. [CrossRef]

56. Ezilarasan, C.; Velayudham, A. Effect of machining parameters on surface integrity in machining Nimonic C-263 super alloy using whisker-reinforced ceramic insert. J. Mater. Eng. Perform. 2013, 22, 1619-1628. [CrossRef]

57. Ezilarasan, C.; Kumar, V.S.; Velayudham, A.; Palanikumar, K. Modeling and analysis of surface roughness on machining of Nimonic C 263 alloy by PVD coated carbide insert. Transactions Nonferr. Met. Soc. 2011, 21, 1986-1994. [CrossRef]

58. Ezilarasan, C.; Kumar, V.S. Effect of machining parameters on micro hardness and residual stresses. Int. Rev. Mech. Eng. 2012, 6, 91-97. 
59. Ezilarasan, C.; Kumar, V.S.; Velayudham, A.; Palanikumar, K. Surface roughness analysis on machining of nimonic C-263 alloy using ANN and RSM techniques. Int. J. Precis. Technol. 2011, 2, 340-354. [CrossRef]

60. Ezilarasan, C.; Kumar, V.S.; Velayudham, A.; Palanikumar, K. Assessment of factors influencing tool wear on machining of nimonic C-263 alloy with PVD coated carbide inserts. Adv. Mater. Res. 2011, 291-294, 794-799. [CrossRef]

61. Ezilarasan, C.V.; Kumar, V.S.; Velayudham, A. Theoretical predictions and experimental validations on machining the Nimonic C-263 super alloy. Simul. Model. Pract. Theory 2014, 40, 192-207. [CrossRef]

62. Thakur, A.; Gangopadhyay, S.; Mohanty, A.; Maity, K. Performance evaluation of CVD multilayer coating on tool wear characteristics during dry machining of Nimonic C-263. In Proceedings of the 5th International \& 26th All India Manufacturing Technology, Design and Research Conference (AIMTDR 2014), IIT Guwahati, Guwahati, India, 12-14 December 2014.

63. Podder, B.; Paul, S. Improvement of machinability in end milling of Nimonic C-263 by application of high pressure coolant. IJMMM 2012, 11, 418-433. [CrossRef]

64. Podder, B.; Paul, S. Effect of machining environment on machinability of Nimonic 263 during end milling with uncoated carbide tool. IJMMM 2008, 3, 104-119. [CrossRef]

65. Wright, P.K.; Chow, J.G. Deformation characteristics of nickel alloys during machining. J. Eng. Mater. Technol. ASME 1982, 104, 85-93. [CrossRef]

66. Lee, S.M.; Chow, H.M.; Yan, B.H. Friction Drilling of IN-713LC Cast Superalloy. Mater. Manuf. Proces. 2007, 2, 893-897. [CrossRef]

67. Ludvík, K.; Lukáš, P.; Konečná, R. High-cycle fatigue of Ni-base superalloy Inconel 713LC. Int. J. Fatigue 2010, $32,908-913$.

68. Zielińska, M.; Yavorska, M.; Poręba, M.; Sieniawski, J. Thermal properties of cast nickel based superalloys. Arch. Mater Sci. Eng. 2010, 44, 35-38.

69. Zlá, S.; Smetana, B.; Žaludová, M.; Dobrovská, J.; Vodárek, V.; Konečná, K.; Matějka, V.; Francová, H. Determination of thermophysical properties of high temperature alloy IN713LC by thermal analysis. J. Therm. Anal. Calorim. 2012, 110, 211-219. [CrossRef]

70. Brehl, D.E.; Dow, T.A. Review of vibration-assisted machining. Precis. Eng. 2008, 32, 153-172. [CrossRef]

71. Thakur, A.; Gangopadhyay, S. State-of-the-art in surface integrity in machining of nickel-based super alloys. Int. J. Mach. Tools Manuf. 2016, 100, 25-54. [CrossRef]

72. Noor, M.M.; Kadirgama, K.; Habeeb, H.N.; Rahman, M.M.; Mohammad, B. Performance of carbide cutting tools when machining of nickel-based alloy. Int. J. Mater. Form. 2010, 3, 475-478. [CrossRef]

73. Polvorosa, R.; Suárez, A.; López de Lacalle, L.N.; Cerrillo, I.; Wretland, A.; Veiga, F. Tool wear on nickel alloys with different coolant pressures: Comparison of Alloy 718 and Waspaloy. J. Manuf. Proc. 2017, 26, 44-56. [CrossRef]

74. Kraus, L.; Zrnik; Wangyao, P.; Nemecek, S. Materials properties of modifeied Ni-based alloy. Metalurgija 2007, 46, 169-172.

75. Devillez, A.; Le Coz, G.; Dominiak, S.; Dudzinski, D. Dry machining of Inconel 718, workpiece surface integrity. J. Mat. Proc. Technol. 2011, 211, 1590-1598. [CrossRef]

76. Eckart, U. Cutting of Inconel and Nickel Base Materials. In CIRP Encyclopedy of Production Engineering; Springer: Cham, Switzerland, 2015; pp. 329-334.

77. Brandt, G. Ceramic cutting tools. Ind. Ceramic. 2007, 21, 21-26.

78. Tian, X.; Zhao, J.; Zhao, J.; Gong, Z.; Dong, Y. Effect of cutting speed on cutting forces and wear in high-speed face milling of Inconel 718 with Sialon ceramic tools. Int. J. Adv. Manuf. Technol. 2013, 69, 2669-2678. [CrossRef]

79. Yazid, M.; Che Haron, C.H.; Ghani, J.A. Tool wear of PVD Coated Carbide Tool when Finish Turning Inconel 718 under high Speed Machining. Adv. Mater. Res. 2010, 129, 1004-1008. [CrossRef]

80. Nalbant, M.; Altin, A.; Gökkaya, H. The effect of cutting speed and cutting tool geometry on machinability properties of nickel-base Inconel 718 super alloys. Mater. Des. 2007, 28, 1334-1338. [CrossRef]

81. Zheng, G.M.; Zhao, J.; Song, X.Y.; Yan, C.Q.; Li, Y.E. Ultra high speed turning of Inconel 718 with SiAlON ceramic tools. Adv. Mater. Res. 2010, 126-128, 653-657. [CrossRef]

82. Zhuang, K.; Zhu, D.; Zhang, X.; Ding, H. Notch wear prediction model in turning of Inconel 718 with ceramic tools considering the influence of work hardened layer. Wear 2014, 313, 63-74. [CrossRef]

83. Altin, A.; Nalbant, M.; Taskesen, A. The effects of cutting speed on tool wear and tool life when machining Inconel 718 with ceramic tools. Mater. Des. 2007, 28, 2518-2522. [CrossRef]

84. Zheng, G.; Zhao, J.; Zhou, Y.; Li, A.; Cui, X.; Tian, X. Performance of graded nanocomposite ceramic tools in ultra-high-speed milling of Inconel 718. Int. J. Adv. Manuf. Technol. 2013, 67, 2799-2810. [CrossRef]

85. Uludag, A.; Turan, D. High temperature bending creep behavior of a multi-cation doped $\alpha / \beta$-SiAlON composite. Ceram. Int 2011, 37, 921-926. [CrossRef]

86. Çelik, A.; Alağaç, M.S.; Turan, S.; Kara, A.; Kara, F. Wear behavior of solid SiAlON milling tools during high speed milling of Inconel 718. Wear 2017, 378, 58-67. [CrossRef]

87. Grigoriev, S.; Pristinskiy, Y.; Volosova, M.; Fedorov, S.; Okunkova, A.; Peretyagin, P.; Smirnov, A. Wire electrical discharge machining, mechanical and tribological performance of TiN reinforced multiscale SiAlON ceramic composites fabricated by Spark Plasma Sintering. Appl. Sci. 2021, 11, 657. [CrossRef]

88. Deshpande, Y.; Andhare, A.; Sahu, N.K. Estimation of surface roughness using cutting parameters, force, sound, and vibration in turning of Inconel 718. J. Braz. Soc. Mech. Sci. Eng. 2017, 39, 5087-5096. [CrossRef] 
89. Choudhury, I.A.; El-Baradie, M.A. Machinability of nickel-base super alloys: A general review. J. Mater. Process. Technol. 1998, 300, 278-284. [CrossRef]

90. Mišković, Z.; Lukić, B.; Gligić, M.; Jovanović, M. The casting and heat treatment of superalloy “444” under vacuum. Vacuum 1990, 40, 125-129. [CrossRef]

91. Tsuda, O.; Kanamaru, N.; Furuta, S.; Takigawa, H.; Iwai, K. PM nickel-base superalloy dual-property disks produced by superplastic forging. Metal. Powder Rep. 1991, 46, 31-35. [CrossRef]

92. Rosen, G.I.; Dirnfield, S.F.; Bamberger, M.; Rosen, A.; Prinz, B. Creep investigation of commercial and improved nickel-based wrought superalloys. Mater. Sci. Eng. A 1993, 172, 15-21. [CrossRef]

93. Wakai, T.; Sakane, M.; Ohnami, M.; Okita, K.; Fukuchi, Y. High Temperature Low-Cycle Fatigue of Friction Welded Joints-Type 304-304 Stainless Steel and Alloy 718-718 Nickel Base Superalloy. J. Eng. Mater. Technol. 1993, 115, 109. [CrossRef]

94. Branco, C.M.; Byrne, J. Fatigue behaviour of the nickel-bassed superalloy IN718 at elevated temperature. Fuel Energy Abstr. 1995, $36,283$.

95. Österle, W.; Li, P.X. Mechanical and thermal response of a nickel-base superalloy upon grinding with high removal rates. Mater. Sci. Eng. A 1997, 238, 357-366. [CrossRef]

96. Darwish, S. Machining of difficult-to-cut materials with bonded tools. Int. J. Adhes. Adhes. 2000, 20, 279-289. [CrossRef]

97. Zaretsky, E.B.; Kanel, G.I.; Razorenov, S.V.; Baumung, K. Impact strength properties of nickel-based refractory superalloys at normal and elevated temperatures. Int. J. Impact Eng. 2005, 31, 41-54. [CrossRef]

98. Alniak, M.O.; Bedir, F. Hot forging behavior of nickel based superalloys under elevated temperatures. Mater. Des. 2010, 31, 1588-1592. [CrossRef]

99. He, D.-G.; Lin, Y.C.; Chen, M.-S.; Chen, J.; Wen, D.-X.; Chen, X.-M. Effect of pre-treatment on hot deformation behavior and processing map of an aged nickel-based superalloy. J. Alloys Compd. 2015, 649, 1075-1084. [CrossRef]

100. Mignanelli, P.M.; Jones, N.G.; Perkins, K.M.; Hardy, M.C.; Stone, H.J. Microstructural evolution of a delta containing nickel-base superalloy during heat treatment and isothermal forging. Mater. Sci. Eng. A 2015, 621, 265-271. [CrossRef]

101. Lei, Y.; Li, X.; Sun, R.; Tang, Y.; Niu, W. Effect of sintering temperature and heat treatment on microstructure and properties of nickel-based superalloy. J. Alloys Compd. 2020, 818, 152882. [CrossRef]

102. Zhang, H.; Zhang, C.; Han, B.; Qiu, J.; Li, H.; Qin, S.; Zhou, H. Evolution of grain boundary character distributions in a cold-deformed Nickel-based superalloy during electropulsing treatment. J. Mater. Res. Technol. 2020, 9, 5723-5734. [CrossRef]

103. Sreenu, B.; Sarkar, R.; Kumar, S.S.S.; Chatterjee, S.; Rao, G.A. Microstructure and mechanical behaviour of an advanced powder metallurgy nickel base superalloy processed through hot isostatic pressing route for aerospace applications. Mater. Sci. Eng. A 2020, 797, 140254. [CrossRef]

104. Bushlya, V.; Zhou, J.; Ståhl, J.-E. Modeling and experimentation on multistage work-hardening mechanism in machining with nose-radiused tools and its influence on machined subsurface quality and tool wear. Int. J. Adv. Manuf. Technol. 2014, 73, 545-555. [CrossRef]

105. Sharman, A.; Dewes, R.C.; Aspinwall, D.K. Tool life when high speed ball nose end milling Inconel 718. J. Mater. Process. Technol. 2001, 118, 29-35. [CrossRef]

106. Prasad, K.; Nagendra, K.; Adarsha, H.; Nagaraj, A.; Ravinarayan, V.; Sandeep, V.; Ranganatha, S.M. Analysis on the Effects of Cut-Outs in Hollow Inconel 718 Gas Turbine Shafts. Open J. Appl. Sci. 2018, 8, 304-313. [CrossRef]

107. Ezugwu, E.O.; Wang, Z.M.; Machado, A.R. The machinability of nickel-based alloys: A review. J. Mater. Process. Technol. 1999, 86, 1-16. [CrossRef]

108. Arunachalam, R.; Mannan, M.A. Machinability of nickel-based high temperature alloys. Mach. Sci. Technol. Int. J. 2000, 4, 127-168. [CrossRef]

109. Wei, F.; Wei, J.; Wang, L.; Zheng, L.; Wang, Y. A review on cutting tool technology in machining of Ni-based superalloys. Int. J. Adv. Manuf. Technol. 2020, 110, 2863-2879.

110. Settineri, L.; Levi, R. Surface Properties and Performance of Multilayer Coated Tools in Turning lnconel. CIRP Ann.-Manuf. Technol. 2005, 54, 515-551. [CrossRef]

111. Khidhir, B.A.; Mohamed, B. Machining of nickel based alloys using different cemented carbide tools. J. Eng. Sci. Technol. 2010, 5, 264-271.

112. Vereschaka, A.; Tabakov, V.; Grigoriev, S.; Sitnikov, N.; Andreev, N.; Milovich, F. Investigation of wear and diffusion processes on rake faces of carbide inserts with Ti-TiN-(Ti,Al,Si)N composite nanostructured coating. Wear 2018, 416-417, 72-80. [CrossRef]

113. Costes, J.P.; Guillet, Y.; Poulachon, G.; Dessoly, M. Tool-life and wear mechanisms of CBN tools in machining of Inconel 718. Int. J. Mach. Tools Manuf. 2007, 47, 1081-1087. [CrossRef]

114. Bushlya, V.; Gutnichenko, O.; Zhou, J.; Avdovic, P.; Ståhl, J.-E. Effects of cutting speed when turning age hardenedinconel 718with pcbn tools of binderless and low-cbn grades. Mach. Sci. Technol. 2013, 17, 497-523. [CrossRef]

115. Xikun, L.; Jing, L.; Like, Q.; Tong, C.; Guanming, Q.; Yanbin, S. Composition, Characteristics and Development of Advanced Ceramic Cutting Tools. J. Rare Earths 2007, 25, 287-294. [CrossRef]

116. Volosova, M.A.; Grigor'ev, S.N.; Kuzin, V.V. Effect of Titanium Nitride Coating on Stress Structural Inhomogeneity in OxideCarbide Ceramic. Part 4. Action of Heat Flow. Refract. Ind. Ceram. 2015, 56, 91-96. [CrossRef]

117. Volosova, M.A.; Grigor'ev, S.N.; Kuzin, V.V. Effect of Tinaium Nitride Coatings on Stress Structural Inhomogeneity in OxideCarbide Ceramic. Part 2. Concentrated Force Action1. Refract. Ind. Ceram. 2015, 55, 487-491. [CrossRef] 
118. Kuzin, V.V.; Grigoriev, S.N.; Fedorov, M.Y. Role of the thermal factor in the wear mechanism of ceramic tools. Part 2: Microlevel. J. Frict. Wear 2015, 36, 40-44. [CrossRef]

119. Kuzin, V.V.; Grigoriev, S.N.; Volosova, M.A. Effect of a TiC Coating on the Stress-Strain State of a Plate of a High-Density Nitride Ceramic Under Nonsteady Thermoelastic Conditions. Refract. Ind. Ceram. 2014, 54, 376-380. [CrossRef]

120. Cui, X.; Zhao, J.; Zhou, Y. and Zheng, G. Damage mechanics analysis of failure mechanisms for ceramic cutting tools in intermittent turning. Eur. J. Mech.-A/Solids. 2013, 37, 139-149. [CrossRef]

121. Kuzin, V.V.; Grigoriev, S.N.; Volosova, M.A. The role of the thermal factor in the wear mechanism of ceramic tools: Part 1. Macrolevel. J. Frict. Wear 2014, 35, 505-510. [CrossRef]

122. Bushlya, V.; Zhou, J.; Avdovic, P.; Ståhl, J.-E. Wear mechanisms of silicon carbide-whisker-reinforced alumina $\left(\mathrm{Al}_{2} \mathrm{O}_{3}-\mathrm{SiCw}\right)$ cutting tools when high-speed machining aged Alloy 718. Int. J. Adv. Manuf. Technol. 2013, 68, 1083-1093. [CrossRef]

123. Byrne, G.; Dornfeld, D.; Denkena, B. Advancing Cutting Technology. CIRP Ann.-Manuf. Technol. 2003, 52, 483-507. [CrossRef]

124. Conaway, H.R. Machining the High Nickel Alloys. In Influence of Metallurgy on Machinability; ASM International: Almere, The Netherlands, 1975; pp. 247-256.

125. Koseki, S.; Inoue, K.; Usuki, H. Damage of Physical Vapor Deposition Coatings of Cutting Tools during Alloy 718 Turning. Precis. Eng. 2015, 44, 41-54. [CrossRef]

126. Hu, Z.; Qin, C.; Chen, X.; Tang, A.; Fang, T.; Yang, Z.; Luo, S.; Mao, M. Chemical-Mechanical Polishing of Cemented Carbide Insert Surface for Extended Tool Life in Turning of GH4169 Nickel-Based Superalloy. Int. J. Precis. Eng. Manuf. 2020, 21, 1421-1435. [CrossRef]

127. Vereschaka, A.S.; Vereschaka, A.A.; Savushkin, G.J.; Sivenkov, A.S. Multilayer nanostructured coatings for cutting tools. Inorg. Mater. Appl. Res. 2014, 5, 522-529. [CrossRef]

128. Vereschaka, A.; Tabakov, V.; Grigoriev, S.; Aksenenko, A.; Sitnikov, N.; Oganyan, G.; Seleznev, A.; Shevchenko, S. Effect of adhesion and the wear-resistant layer thickness ratio on mechanical and performance properties of ZRN -(ZR,AL,SI) N coatings. Surf. Coat. Technol. 2019, 357, 218-234. [CrossRef]

129. Vereschaka, A.S.; Grigoriev, S.N.; Tabakov, V.P.; Sotova, E.S.; Vereschaka, A.A.; Kulikov, M.Y. Improving the Efficiency of the Cutting Tool Made of Ceramic when Machining Hardened Steel by Applying Nano-Dispersed Multi-Layered Coatings. Key Eng. Mater. 2013, 581, 68-73. [CrossRef]

130. Arunachalam, R.M.; Mannan, M.A. Performance of CBN cutting tools in facing of age hardened Inconel 718 . Conf. Trans. NAMRI/SME 2004, 32, 525-532.

131. Harris, T.K.; Brookes, E.J.; Taylor, C.J. The effect of temperature on the hardness of polycrystalline cubic boron nitride cutting tool materials. Int. J. Refract. Met. Hard Mater. 2004, 22, 105-110. [CrossRef]

132. Kaya, E.; Kaya, İ. Tool wear progression of PCD and PCBN cutting tools in high speed machining of NiTi shape memory alloy under various cutting speeds. Diam. Relat. Mater. 2020, 105, 107810. [CrossRef]

133. Zhao, J. The use of ceramic matrix composites for metal cutting applications. Adv. Ceram. Matrix Compos. 2014, 623-654.

134. Coelho, R.T.; Silva, L.R.; Braghini, A.; Bezerra, A.A. Some effects of cutting edge preparation and geometric modifications when turning INCONEL 718 ${ }^{\mathrm{TM}}$ at high cutting speeds. J. Mater. Process. Technol. 2004, 148, 147-153. [CrossRef]

135. Cui, E.; Zhao, J.; Wang, X.; Song, S. Cutting performance, failure mechanisms and tribological properties of GNPs reinforced $\mathrm{Al}_{2} \mathrm{O}_{3} / \mathrm{Ti}(\mathrm{C}, \mathrm{N})$ ceramic tool in high speed turning of Inconel 718. Ceram. Int. 2020, 47, 18075-18083. [CrossRef]

136. Guo, F.; Yuan, J.; Hong, D.; Yin, Z. Influence of powder mixing process on phase composition, microstructure, and mechanical properties of $\alpha / \beta$-SiAlON ceramic tool materials. Ceram. Int. 2021, 47, 30256-30265.

137. Joshi, B.; Gyawali, G.; Lee, S.W. Recent advances in transparent/translucent polycrystalline Sialon ceramics. Lett. Mater. 2020, 10, 158-163. [CrossRef]

138. Kshetri, Y.K.; Kamiyama, T.; Torii, S.; Jeong, S.H.; Kim, T.-H.; Choi, H.; Lee, S.W. Electronic structure, thermodynamic stability and high-temperature sensing properties of Er- $\alpha$-SiAlON ceramics. Sci. Rep. 2020, 10, 1-13. [CrossRef]

139. Cao, G.Z.; Metselaar, R. .alpha.'-Sialon ceramics: A review. Chem. Mater. 1991, 3, 242-252. [CrossRef]

140. Hakeem, A.S.; Khan, M.; Ahmed, B.A.; Ghanim, A.A.; Patel, F.; Ehsan, M.A.; Ali, S.; Laoui, T.; Ali, S. Synthesis and characterization of alkaline earth and rare earth doped sialon Ceramics by spark plasma sintering. Int. J. Refract. Met. Hard Mater. 2021, 97, 105500. [CrossRef]

141. Holzer, S.; Häntsche, J.P.; Spicher, U.; Badenheim, D.; Oberacker, R.; Hoffmann, M.J. Development of sialon ceramics for lubricated sliding applications. Materialwissenschaft Werkstofftechnik 2005, 36, 117-121. [CrossRef]

142. Falk, L.K.L.; Shen, Z.-J.; Ekström, T. Microstructural stability of duplex $\alpha-\beta$-sialon ceramics. J. Eur. Ceram. Soc. 1997, 17, 1099-1112. [CrossRef]

143. Hampshire, S. Silicon Nitride Ceramics-review of structure, processing and properties. J. Achiev. Mater. Manuf. Eng. 2007, 24.

144. Ekström, T. $\alpha$ SiAlON and $\alpha$ - $\beta$ SiAlON Composites Recent Research. Eng. Ceram. '96 High. Reliab. Process. 1997, 25, 147-167.

145. Salamon, D.; Šajgalík, P.; Liška, M. Mechanical Properties and Microstructure of $\alpha$-SiAlON Based Cutting Tools. Key Eng. Mater. 2005, 290, 250-253. [CrossRef]

146. Rosenflanz, A.; Chen, I.-W. Phase Relationships and Stability of $\alpha^{\prime}$-SiAlON. J. Am. Ceram. Soc. 1999, 82, 1025-1036. [CrossRef]

147. Mandal, H.; Hoffmann, M.J. Preparation of Multiple-Cation alpha-SiAlON Ceramics Containing Lanthanum. J. Am. Ceram. Soc. 1999, 82, 229-232. [CrossRef] 
148. Cozzan, C.; Griffith, K.J.; Laurita, G.; Hu, J.G.; Grey, C.P.; Seshadri, R. Structural evolution and atom clustering in $\beta$-SiAlON: ß-Si6-zAlzOzN8-z. Inorg. Chem. 2017, 56, 2153-2158. [CrossRef]

149. Hou, X.M.; Yue, C.S.; Zhang, M.; Chou, K.C. Thermal oxidation of SiAlON powders synthesized from coal gangue. Int. J. Miner. Metall. Mater. 2011, 18,77-82. [CrossRef]

150. Li, Y.; Liu, D.; Jin, H.; Ding, D.; Xiao, G.; Shi, Z.; Jin, Z. Effect of Z values on the microstructure and mechanical properties of post-sintered reaction bonded $\beta$-SiAlON. High Tem. Mater. Process. 2017, 36, 453-458. [CrossRef]

151. Zhang, M.; Chen, Z.; Huang, J.; Wang, S.; Xiong, Q.; Feng, Z.; Liu, Q.; Sun, Z.; Li, X. In situ nitriding reaction formation of $\beta$-Sialon with fibers using transition metal catalysts. Ceram. Int. 2019, 45, 21923-21930. [CrossRef]

152. Xiong, Q.M.; Chen, Z.; Huang, J.T.; Zhang, M.; Song, H.; Hou, X.F.; Li, X.B.; Feng, Z.J. Preparation, structure and mechanical properties of sialon ceramics by transition metal-catalyzed nitriding reaction. Rare Met. 2020, 39, 589-596. [CrossRef]

153. Riley, F.L. Silicon nitride and related materials. J. Am. Ceram. Soc. 2004, 83, 245-265. [CrossRef]

154. Izhevskiy, V.A.; Genova, L.A.; Bressiani, J.C.; Aldinger, F. Progress in SiAlON ceramics. J. Eur. Ceram. Soc. 2000, 20, $2275-2295$. [CrossRef]

155. Jack, K.H. Review: Sialon and related nitrogen ceramics. J. Mater. Sci. 1976, 11, 1135-1158. [CrossRef]

156. Zhuo, T.; Yuping, Y.; Yong, W.; Haidong, W.; Wei, L.; Shanghua, W. The shrinkage, phase composition and mechanical properties of ceramics with different $\beta$-sialon main crystalline phases prepared by stereolithography. Ceram. Silik. 2020, 64, 1-9.

157. Low, I.M. Ceramic-Matrix Composites. Microstructure, Properties and Applications; Elsevier: Amsterdam, The Netherlands, 2006; pp. 491-513. ISBN 1855739429.

158. Ekström, T. Effect of composition, phase content and microstructure on the performance of Yttrium-Si-Al-O-N ceramics. Mater. Sci. Eng. 1989, A109, 341-349. [CrossRef]

159. Mandal, H.; Kara, F.; Turan, S.; Kara, A. Novel SiAlON Ceramics for Cutting Tool Applications. Key Eng. Mater. 2003, 237, 193-202. [CrossRef]

160. Bitterlich, B.; Bitsch, S.; Friederich, K. SiAlON based ceramic cutting tools. J. Eur. Ceram. Soc. 2008, 28, 989-994. [CrossRef]

161. Fernandez-Lucio, P.; Neto, O.P.; Gomez-Escudero, G.; Fuertes, F.J.A.; Valdivielso, A.F.; Lopez de Lacalle Marcaide, L.N. Roughing milling with ceramic tools in comparison with sintered carbide on nickel-based alloys. Coatings 2021, 11, 34. [CrossRef]

162. Krebs, G.; Polli, M.L. Cutting Parameters for Roughing Turning of Alloy 625 Clad Using Ceramic Inserts. Mater. Res. 2019, 22, e20190535. [CrossRef]

163. Liu, J.; Ma, C.; Tu, G.; Long, Y. Cutting performance and wear mechanism of Sialon ceramic cutting inserts with TiCN coating. Surf. Coat. Technol. 2016, 307, 146-150. [CrossRef]

164. Zheng, G.; Zhao, J.; Cheng, X.; Xu, R.; Zhao, G. Experimental Investigation on Sialon Ceramic Inserts for Ultra-high-speed Milling of Inconel 718. Mater. Manuf. Process. 2015, 31, 633-640. [CrossRef]

165. Ingelström, N.; Ekström, T. Relation between composition, microstructure and cutting tool performance of Alpha-Beta-SiAlONs. J. Phys. Colloq. 1986, 47, 347-352. [CrossRef]

166. Lima, F.F.; Sales, W.F.; Costa, E.S.; da Silva, F.J.; Machado, Á.R. Wear of ceramic tools when machining Inconel 751 using argon and oxygen as lubri-cooling atmospheres. Ceram. Int. 2017, 43, 677-685. [CrossRef]

167. Kasim, M.S.; Haron, C.H.; et al. Multi-Objective Optimization Using Box-Behken of Response Surface Methodology for HighSpeed Machining of Inconel 718. Appl. Mater. 2014, 629, 487-492. [CrossRef]

168. Sarkar, B.; Reddy, M.M.; Debnath, S. Effect of machining parameters on surface finish of Inconel 718 in end milling. MATEC Web Conf. 2017, 02009, 1-6. [CrossRef]

169. Zheng, G.; Zhao, J.; Zhou, Y. Friction and wear behaviors of Sialon- $\mathrm{Si}_{3} \mathrm{~N}_{4}$ graded nano-composite ceramic materials in sliding wear tests and in cutting processes. Wear 2012, 290-291, 41-50. [CrossRef]

170. Shalaby, M.A.; Veldhuis, S. Effect of Cutting Speed on Chipping and Wear of the SiAlON Ceramic Tool in Dry Finish Turning of the Precipitation Hardenable IN100 Aerospace Superalloy. J. Tribol. 2018, 141, 021604. [CrossRef]

171. Zhou, J.; Bushlya, V.; Peng, R.L.; Chen, Z.; Johansson, S.; Stahl, J.E. Analysis of Subsurface Microstructure and Residual Stresses in Machined Inconel 718 with PCBN and $\mathrm{Al}_{2} \mathrm{O}_{3}-\mathrm{SiC}_{\mathrm{W}}$ Tools. Procedia CIRP 2014, 13, 150-155. [CrossRef]

172. Ibrahim, G.A.; Che Haron, C.H.; Ghani, G.A.; Said, A.Y.M. Performance of PVD and CVD coated tools when machining nickel-based, Inconel 718 alloy. Adv. Mech. Eng. 2011, 3, 1-10. 